\title{
Review of Host Trees for the Wood-Boring Pests Anoplophora glabripennis and Anoplophora chinensis: An Urban Forest Perspective
}

\author{
Henrik Sjöman, Johan Östberg, and Johan Nilsson
}

\begin{abstract}
Two devastating insect pests have been introduced to North America and Europe - the Asian longhorned beetle (ALB) (Anoplophora glabripennis) and the citrus longhorned beetle (CLB) (Anoplophora chinensis). These two wood-boring beetles are argued to be one of the most serious threats to the tree landscape since they have a large number of host species and genera. With the aim of creating an up-to-date compilation of these hosts, a systematic review was made of the literature for information on tree species attacked and used by ALB and CLB as hosts for complete life cycle or for feeding. This review revealed that a large number of tree species and genera are liable to be attacked by ALB and CLB. However, based on the findings, the whole picture is still unclear. One reason for this is the lack of transparency in published studies regarding lists of susceptible tree species for ALB and CLB. Another factor that needs to be reported is whether a tree species supports the complete life cycle of the beetles or just feeding by adult beetles. Without this information, species possessing moderate host qualities are at risk of being incorrectly labelled as very good hosts and hence excluded as urban trees.

Key Words. Anoplophora chinesis; Anoplophora glabripennis; Asian Longhorned Beetle; Citrus Longhorned Beetle; Host; Pests; Review; Tree Selection; Urban Trees; Wood-boring Pests.
\end{abstract}

Today, the urban forest and its constituent trees are much more than an aesthetic green element in cities. Aspects such as biological diversity, stormwater management, pollution relief, beneficial and recreational impacts on human well-being, and urban heat island mitigation are some of the services urban tree vegetation provides for city dwellers (Forman and Godron 1986; Grahn and Stigsdotter 2003; Maco and McPherson 2003; Tyrväinen et al. 2005; Geldof and Stahre 2006; Nowak et al. 2006; King and Davis 2007). In the compact city, the qualities provided in large parks and green areas will be compressed into smaller scale units or alternative green structures, increasing the demands on capacity load and performance level of future urban green space and future urban trees (Sjöman et al. 2012a). Since trees are long-lived organisms and their capacity to deliver ecosystem services is not completely developed until they are fully grown individuals, it is of the utmost importance that the trees selected today last into the future. However, today's urban trees and forests are facing great difficulties with pests and diseases and with a chang- ing climate, which can compromise their future development and functions. It is therefore important to determine which species and genera of trees can meet these future challenges (Sjöman et al. 2012b).

In the last decades, two important and devastating insect pests have been introduced to North America and Europe - the Asian longhorned beetle (ALB) (Anoplophora glabripennis) and the citrus longhorned beetle (CLB) (Anoplophora chinensis). These two wood-boring beetles are argued to be one of the most serious threats to the tree landscape since they have a large number of host species and genera (e.g., MacLeod et al. 2002; Raupp et al. 2006; Hu et al. 2009; Haack et al. 2010). Well-known hosts for ALB in China include species of Acer, Alnus, Betula, Eleagnus, Fraxinus, Malus, Platanus, Populus, Pyrus, Salix, Sophora, and Ulmus (Haack et al. 2010). In the United States, ALB has completed development on species in the genera Acer, Betula, Fraxinus, Pyrus, Salix, and Ulmus, but also in species of Robinia (Haack et al. 2010), indicating that this beetle is expanding its host range as it invades new territories and encounters new potential host 
species with devastating biological and economic consequences. For example, Nowak et al. (2001) used tree inventories to estimate potential monetary losses resulting from ALB in nine cities in the United States and reported an estimated loss of approximately 1.2 billion trees, at a compensatory value of USD $\$ 669$ billion. To combat pests such as the longhorned beetle, providing a large diversity of tree species and genera is argued to be one of the most important solutions. Therefore, it is essential, in the long-term planning of the urban treescape, to use tree species and genera that face a minimal risk of being attacked by these two wood-boring pests.

The aim of this study was to create an up-todate compilation of the tree species that ALB and CLB attack and use as hosts for a complete life cycle or for feeding. A systematic literature survey (Wright et al. 2007) was conducted to identify relevant species and the findings were assessed in terms of origin, method used, and any weaknesses and limitations in the information provided.

\section{MATERIALS AND METHODS}

\section{Biology and Distribution of the Longhorned Beetles}

To understand the information presented in the review and the following discussion, it is important to understand the biology and distribution of the two longhorned beetle species. The native range of ALB includes China and Korea, while that of CLB also includes Japan with occasional records from Indonesia, Malaysia, Philippines, Taiwan, and Vietnam (Lingafelter and Hoebeke 2002). The life cycles of ALB and CLB are similar and well described (Haack et al. 2010). Adult beetles undergo a one- to two-week period of maturation, feeding on foliage and tender bark on the twigs of host trees before beginning to reproduce (Keena 2002; Smith et al. 2002). The females of ALB chew slits or funnel-shaped holes through the bark of host trees and lay their eggs under the bark, while CLB females only chew slits before laying the eggs. Only a single egg is laid in each oviposition site (Lingafelter and Hoebeke 2002; Hérard et al. 2006). ALBs typically initiates oviposition along the upper trunk and main branches (Haack, 2006), whereas CLBs usually lay eggs along the lower trunk, root collar region, and on exposed roots (Hérard et al. 2006). Larvae feed in the cambium and then bore into the wood, where they continue to feed, eventually forming a pupal chamber. Larval boring produces structural weakness and disrupts the flow of water and nutrients within host trees, leading to death of branches and ultimately whole trees. Adult feeding on twigs and foliage is considered of minor importance, except occasionally on fruit-bearing trees. Most damage results from larval tunneling in the cambial regions and wood. Both species attack healthy and stressed trees, varying in size from small bonsai and potted trees (especially CLB) to mature trees (Haack et al. 2010).

Outside their native range, both ALBs and CLBs have caused tree mortality and are ranked as highrisk quarantine pests (MacLeod et al. 2002). Both ALB and CLB have been intercepted in wood packaging material associated with imports, such as steel, ironware, pottery, and other materials, as well as in living plants, such as bonsai or nursery stocks originating primarily from China. The main introduction of ALB into new regions has been through wood packaging material, while CLB has mainly been introduced through living plants (Haack et al. 2010). The first discovery of an established population of ALB outside of its native range was in North America in 1996 (Haack et al. 1997), and that of CLB in Europe in 2000 (Hérard et al. 2006).

\section{Host Tree Review}

The literature reviewed to find information concerning host trees for ALB and CLB included scientific articles and official documents concerning invasive pests. The search included the Google Scholar, Scopus, and CAB abstract databases (ISI Web of Knowledge), and the reference lists within the publications found in these databases. In the initial search in the databases, the search terms used were: Asian longhorn beetle, citrus longhorn beetle, ALB, CLB, Anoplophora glabripennis, and Anoplophora chinensis. Since Anoplophora malasiaca is argued to be a synonym of $A$. chinensis (Lingafelter and Hoebeke 2002), researchers also included this name in the search. In the compilation of literature, the search was limited to publications written in English, Swedish, Norwegian, Danish, Dutch, French, German, and Italian. For publications written in Chinese and Japanese with an abstract in English, only the abstract was included. 
In total, 35 publications were found with information concerning host species for these two longhorned beetles. The suitability of tree species as hosts was ranked as: very good host, good host, host, and rare/resistant based on information in the literature reviewed-for definitions used to classify hosts, see Table 1 (Yin and Lu 2005). In the publications studied (Appendix 1; Appendix 2; Table 2), there was lack of consistent information on whether there is a complete life cycle of the beetles in the trees or if the adult beetles were simply feeding. When the information was imprecise regarding how a beetle attacks and feeds on a tree species, the species was ranked provisionally as a host. Information regarding the possibility for larva development by the beetles was included for all species (Appendix 1; Appendix 2).

The information found in the review was then further analyzed in terms of aspects such as the origin of the findings [i.e., whether the information had been obtained through controlled greenhouse studies or studies in natural environments or plantations (Appendix 3)]. The geographical focus of the study was also included, as were any citations of the publication in the Scopus database. Host-related information within the studies was also analyzed to trace its origin (Appendix 3).

\section{RESULTS AND DISCUSSION}

Of the 35 papers reviewed, 29 contained information on host trees for ALB, while only 13 had corresponding information for CLB. The total number of papers exceeded 35, since some studies covered both ALB and CLB and were therefore counted twice (Appendix 1; Appendix 2; Appendix 3; Table 2).

In the compilation of host trees for ALB, 36 species were mentioned as a host to some degree, while 31 genera were described as being at risk of attack-these genera obviously included many more than 36 species. The species described most frequently as a host to some degree was Acer platanoides, followed by $A$. saccharum and A. negundo. The genera described most comprehensively as a good host for ALB were Populus spp., Salix spp., and Acer spp., followed by Betula spp., Ulmus spp., and Platanus spp. (Appendix 1).

In the compilation of host trees for ALB, there were also 31 species and 16 genera that were described as resistant or rarely infested (Appendix 1). However, as can be seen from Appendix 1, there were some clear contradictions concerning which species and genera were susceptible. For example, some publications described a particular genus or species as a host to some degree, while others described them as resistant or rarely infested. Further, five publications described Tilia spp. as a host for ALB (Nowak et al. 2001; Ric et al. 2006; Hu et al. 2009; Jordbruksverket 2010; APHIS 2012), while two other publications stated that the genus of lime trees is rarely affected or even resistant (Haack et al. 1997; Raupp et al. 2006). This contradiction regarding which species can be characterized as hosts is even more pronounced in studies focusing on poplar trees (Populus spp.) and their susceptibility to ALB. Since there has been enormous use of poplar trees to counteract desertification in northwestern China, several studies evaluate these poplar plantations and outbreaks of ALB (Lingafelter and Hoebeke 2002; Yin and Lu 2005; Yang 2005; Hu et al. 2009 and references therein). In these studies, it is obvious that not all poplar species are classified as a very good host for ALB, even if the genus is described as one of the

Table 1. Division of host susceptibility into: very good host, good host, host, and rare/resistant.

\begin{tabular}{lll}
\hline Host grade & ALB and CLB feeding and life cycle features & Impact on tree growth \\
\hline Very good host & $\begin{array}{l}\text { Attracts longhorned beetles. Extensive feeding } \\
\text { by adult beetles. Complete life cycle with population } \\
\text { increase }\end{array}$ & $\begin{array}{l}\text { Dieback of whole tree crown } \\
\text { or entire tree }\end{array}$ \\
Good host & Moderate feeding. Can complete life cycle & $\begin{array}{l}\text { Dieback on some branches. Dieback } \\
\text { of whole tree crown or entire tree } \\
\text { if stressed }\end{array}$ \\
Host & $\begin{array}{l}\text { Limited feeding by adult beetles. Small number of } \\
\text { eggs laid. Can escape attack if nearby trees are } \\
\text { more susceptible }\end{array}$ & $\begin{array}{l}\text { Normal growth. Slight damage } \\
\text { with recovery wounds }\end{array}$ \\
$\begin{array}{l}\text { Resistant or } \\
\text { rarely affected }\end{array}$ & No feeding activity by adult beetles; no eggs laid & Normal growth
\end{tabular}


Table 2. Categorization of poplar species as hosts for ALB according to Gao et al. (1997), Ludwig et al. (2002), Wang (2004), Yin and Lu (2005), Yang (2005), and Hu et al. (2009).

\begin{tabular}{|c|c|c|}
\hline Category & Species/hybrids & Section \\
\hline Very good hosts & $\begin{array}{l}\text { Populus nigra: 'Pyramidalis', 'Italica,' 'Thevestina' } \\
\text { Populus deltoides 'Brangarsi' } \\
\text { Populus } \times \text { euramericana: 'Luisa Avanzo', 'Bellini', 'Guardi' } \\
\text { Populus } \times \text { xiaozhuannica, P. } \times \text { xiaozhuannica: 'Opera,' 'Popularis' }\end{array}$ & $\begin{array}{l}\text { Aigeiros } \\
\text { Aigeiros } \\
\text { Aigeiros } \\
\text { Aigeiros } \times \text { Tacamahaca }\end{array}$ \\
\hline Good hosts & $\begin{array}{l}\text { Populus nigra } \\
\text { Populus deltoides } \\
\text { Populus lasiocarpa } \\
\text { Populus pseudoglauca } \\
\text { Populus cathayana } \\
\text { Populus gansuensis } \\
\text { Populus pseudosimonii } \\
\text { Populus simonii } \\
\text { Populus ussuriensis } \\
\text { Populus simonii } \times \text { P. nigra 'Pyramidalis': 'Baichensis', 'Taiqing', 'Italica' } \\
\text { Populus nigra } \times \text { P. simonii } \\
\text { Populus } \times \text { beijingensis } \\
\text { Populus } \times \text { berolinensis } \\
\text { Populus } \times \text { dakuanensis } \\
\text { Populus } \times \text { russki } \\
\text { Populus stalinetz } \\
\text { Populus } \times \text { xiaohei, } P . \times x i a o h e i \text { 'Heilin-1' }\end{array}$ & $\begin{array}{l}\text { Aigeiros } \\
\text { Aigeiros } \\
\text { Leucoides } \\
\text { Leucoides } \\
\text { Tacamahaca } \\
\text { Tacamahaca } \\
\text { Tacamahaca } \\
\text { Tacamahaca } \\
\text { Tacamahaca } \\
\text { Aigeiros } \times \text { Tacamahaca } \\
\text { Aigeiros } \times \text { Tacamahaca } \\
\text { Aigeiros } \times \text { Tacamahaca } \\
\text { Aigeiros } \times \text { Tacamahaca } \\
\text { Tacamahaca } \\
\text { Aigeiros } \\
\text { Aigeiros } \\
\text { Aigeiros } \times \text { Tacamahaca }\end{array}$ \\
\hline Occasional hosts & $\begin{array}{l}\text { Populus deltoides: 'Nankang', 'Qingji \#1, 2', 'Shanhaiguan', 'pyramidalis' } \\
\text { Populus balsamifera } \\
\text { Populus alba 'Pyramidalis' } \\
\text { Populus alba } \times \text { Populus bolleana } \\
\text { Populus alba } \times \text { Populus tomentosa } \\
\text { Populus deltoides } \times \text { P. simonii } \\
\text { Populus } \times \text { euramericana }(=\text { P. } \times \text { canadensis }) \\
\text { Populus } \times \text { euramericana 'Veruirubens', 'Vegeherata 272', 'G-158', 'I-214', } \\
\text { 'Triplo', Gattoni', 'Cima' }\end{array}$ & $\begin{array}{l}\text { Aigeiros } \\
\text { Tacamahaca } \\
\text { Populus } \\
\text { Populus } \\
\text { Populus } \\
\text { Aigeiros } \times \text { Tacamahaca } \\
\text { Aigeiros } \\
\text { Aigeiros }\end{array}$ \\
\hline $\begin{array}{l}\text { Rare hosts or } \\
\text { resistant hosts }\end{array}$ & $\begin{array}{l}\text { Populus euphratica, P. euphratica: 'Pyramidalis', 'PE-214' } \\
\text { Populus pruinosa } \\
\text { Populus alba } \\
\text { Populus davidiana } \\
\text { Populus hopeiensis } \\
\text { Populus tomentosa, P. tomentosa 'Hopeinica', 'Honanica' } \\
\text { Populus tremula } \\
\text { Populus tremuloides }\end{array}$ & $\begin{array}{l}\text { Turanga } \\
\text { Turanga } \\
\text { Populus } \\
\text { Populus } \\
\text { Populus } \\
\text { Populus } \\
\text { Populus } \\
\text { Populus }\end{array}$ \\
\hline
\end{tabular}

most susceptible (Appendix 1 and Table 2). In the division between poplar species with differing susceptibility to ALB, it is obvious that there are differences between sections in the genus, with species within the sections Populus and Turanga even being classified as resistant or rarely infested (Table 2).

The compilation on CLB included fewer publications describing host trees. However, the number of host species described was much greater than for ALB. In total, 108 species were described as a potential host for CLB, while the number of genera was 73 (Appendix 2). In the literature reviewed, no species or genus was described as resistant or rarely affected by CLB. The species described most frequently as a host to some degree were Acer palmatum and A. platanoides, followed by A. pseudoplatanus and Aesculus hippocastanum. The genera described most comprehensively as a good host for CLB were Acer spp., Malus spp., and Citrus spp., followed by Populus spp. and Platanus spp. (Appendix 2).

In an attempt to make an up-to-date compilation of host trees for ALB and CLB, researchers identified great confusion in the literature, which weakened the information and may lead to incorrect conclusions and recommendations. In host-related publications, there was much cross-referencing between the papers, making it difficult to identify the origin of the information and how it was obtained. Since a large proportion of the publications on ALB are in Chinese, it is even more difficult to evaluate the background to the conclusions presented in abstracts. Later publications, basing their information on Chinese and Japanese studies (e.g., Haack et al. 1997; Nowak et al. 2001; Lingafelter and Hoebeke 2002; Yin and Lu 2005; Yang 2005; Hu et al. 2009), 
mainly presented the findings quantitatively with a concluding list of susceptible species, and without a qualitative description of how these conclusions were reached. For example, Yang (2005) and Yin and $\mathrm{Lu}$ (2005) reviewed Chinese research concerning ALB but presented the findings very briefly and without an introduction to the methodology and approach used in the studies. This might be the reason why there are some contradictions regarding the suitability of different species and genera in Appendix 1. Furthermore, it is often unclear whether the findings listed in the appendices and Table 2 refer to damage by adult beetles, as specified by Ludwig et al. (2002), Morewood et al. (2003), and Morewood et al. (2004a), or refer to use of the trees for oviposition and larval development. Such information is rarely presented in the publications reviewed, which weakened the information and leads to further confusion.

In the compilation of host trees for the two longhorned beetles, there was a rather large amount of information concerning tree genera, which of course include many more species than those listed in the appendices and Table 2. Including whole genera as a host, for example, CLB may cause the use of a whole genus to be banned, even if there are just a few species that are susceptible and the rest are resistant or rarely affected. When interpreting information from one study in another, it is tempting to simplify the information. An example is Van der Gaag et al. (2010), presenting a list of hosts for CLB based on original data in Lingafelter and Hoebeke (2002), most of which was in turn based on information in Chinese and Japanese studies (Appendix 3). Lingafelter and Hoebeke (2002) listed a large number of species as hosts for CLB, but in the compilation by Van der Gaag (2010), much of this species information was changed to whole genera, without further information. This simplification of host-related information can result in great confusion and misunderstanding, especially if it is used by national authorities to formulate recommendations on trees to avoid in example urban environments. The present review uncovered clear evidence that there are species within highly susceptible genera that are resistant or rarely affected. For example, Williams et al. (2004) evaluated 12 maple species in native communities of South Korea for ALB damage and found that only five species (three native and two invasive exotic species) had visible damage or adult ALB, leaving seven species with no observed damage. Furthermore, even within the poplar genus, which is considered the most susceptible to ALB, there is evidence that sections within this genus are resistant or rarely affected (Weilun and Wen 2005). In a compilation by Hu et al. (2009) based on data from Yin and $\mathrm{Lu}$ (2005) and Gao et al. (1997), poplar species belonging to the section Turanga (e.g., Populus pruinosa Schrenk) and Populus (e.g., Populus alba L., $P$. tomentosa Carr., and P. tremula L.) were listed as less susceptible or slightly resistant to ALB (Bao et al. 1999; Table 2). These examples of resistant species within highly susceptible genera might indicate that there has been generalization regarding the species and genera classified as hosts. If several species have been shown to be susceptible to ALB, it is easy to conclude that the whole genus is susceptible.

The fact that the first discovery of longhorned beetles outside their native range took place in 1996 in New York (ALB) (Lingafelter and Hoebeke 2002) is reflected in the geographical focus of the publications reviewed. ALB host-related publications older than 1996 were mainly produced in China, Japan, and Taiwan (Appendix 3), while publications later than 1996 had a greater focus on North America. CLB host-related publications later than the year 2000 mainly had a European focus, following the first recognized outbreak in Europe (Appendix 3).

Information about whether a tree species is a host, good host, or very good host was fairly commonly provided in the literature reviewed. However, it was more difficult to find clear definitions of the terms used to describe the kind of damage done by the beetles to the tree. Terms used commonly in the literature were: infested, attacked, host, and feeding. For the beetles to become established in an area they not only need to find food, but also to be able to propagate, which means finding suitable tree species for oviposition and larval development into fully developed beetles. Ric et al. (2006) noted that not all tree species are suitable for the whole reproduction cycle. For example, some species are suitable for oviposition but not larval development. Other species are used for feeding by the adult beetles but not for oviposition. The terms infested, attacked, host, and feeding do not clearly describe whether the tree is used for feeding by adults or whether full larval development is possible. Haack et al. (1997) used "primary host tree" and "occa- 
sional host tree," "attack primarily" and "complete development" in the "Range and Life Cycle" section for ALB. Hérard et al. (2006) mentioned infested trees and host plants without specifying the meaning, and stated that certain species were preferred host plants, but not whether this meant feeding, oviposition, or full development. FAO (2007) explained that the larvae injure the tree by tunnels under the bark and bore into wood, but when listing trees species it stated "the main genera of trees that it feeds on are. ." This is confusing, as adult beetles feed on some trees but oviposition and larval development do not always occur on the same species as adult feeding. The Danish Natural Agency (Naturerhvervstyrelsen 2012) concluded that one should distinguish between host plants where the beetles can undergo full development, and host plants where the adults feed on the trees. There are several examples of rating systems that include the possibility of a reproductive cycle for the species. For example, Yin and $\mathrm{Lu}$ (2005) used a scale from 1 to 5 to rate tree species, where grades 3 to 5 included the ALB being able to complete a life cycle. Ric et al. (2006) used a three-point rating system, where 1 was suitable for the entire life cycle, 2 was where the beetles had laid eggs but there was no evidence that a whole cycle was possible, and 3 was for species with unknown suitability for beetle larval development.

Among the studies concerning ALB, Ludwig et al. (2002), Smith et al. (2002), MacLeod et al. (2002), Morewood et al. (2003; 2004a; 2004b; 2005), Auclair et al. (2005), and Hajek and Kalb (2007) had obtained their host-related information from greenhouse tests, while the remaining publications appeared to refer to cases and observations in native communities or in public plantations. Only one of the 13 studies of CLB reviewed had obtained host-related information from greenhouse tests (Adachi 1994; Appendix 3). To develop more accurate species-related information concerning susceptibility to ALB and CLB, some authors point out that controlled laboratory tests are needed (MacLeod et al. 2002; Morewood et al. 2004a). However, when beetles are introduced to one or few species in a controlled environment, they may use less favorable species in the absence of more susceptible species. Therefore, host-related conclusions from controlled laboratory or greenhouse tests must be thoroughly analyzed. How- ever, if a species in these tests shows resistance to the beetles, this could be important information. In the review by Yin and $\mathrm{Lu}$ (2005), a number of tree species native to China were classified as resistant or rarely affected by ALB (Appendix 1). In fact, the majority of the species/genera classified as resistant or rarely affected by ALB in Appendix 1 are native to China and Japan, where they have been living for generations, side-by-side with the beetle and might have developed natural strategies to avoid attacks. For example, there may be chemical substances in the wood making it unattractive for feeding or unsuitable to support complete development of the ALB (Morewood et al. 2004a). Once the biochemical basis of resistance against ALB and CLB is elucidated, researchers may have a greater understanding of species that are superior to use, while any biocidal compounds produced could perhaps be manipulated to help protect more vulnerable trees from these pests. In the study by Morewood et al. (2004a), an evaluation of four tree species for ALB in controlled greenhouse conditions showed that the Chinese callery pear (Pyrus calleryana) was most likely to cause adult mortality of the beetle. No larvae survived, although eggs in callery pear hatched and the neonates began to feed and construct galleries in the wood. In work on ALB and CLB, it is interesting to know not only which species are resistant or rarely affected by these beetles, but also why they are resistant or rarely affected.

Data on citations of host-related information within thepublications reviewed here clearly revealed a large number of cross-references, especially among recent studies. For example, the paper by Lingafelter and Hoebeke (2002) was included in six other publications as a host-related reference, but they in turn based their host-related information mainly on older Chinese and Japanese studies (Appendix 3). This pattern of much older host-related information originating from Chinese studies, especially for ALB, makes it difficult to analyze the methodology and approach used in the studies or to evaluate from where and how the conclusions were developed. The most frequently cited publication within this review (that by Nowak et al. 2001) used three Chinese studies (in Chinese) and two unpublished sources from North America as the basis for a host-related evaluation. More recent studies from North America and Europe make a much more transparent presentation 
of the studies, which makes it possible to evaluate the findings. However, the international reviews included within the present study (Lingafelter and Hoebeke 2002; Hu et al. 2009; Haack et al. 2010) based much of their host-related information on Chinese studies, written in Chinese (Appendix 3).

Furthermore, it is important to know the environments in which the beetles have been studied. In forest types, where very good hosts are absent, the beetles use more "non-traditional" species and genera to a much larger amount than when more suitable host trees are available. This scenario can lead to one author reporting that a species or genus is a very good host and another concluding that the same species or genus is rarely or never infested. Among the publications reviewed, eight based their host-related information for ALB and CLB on natural environments or plantations (Appendix 3) but provided no information on the species composition, structure, or succession phase of the habitat or plantations studied. This makes it difficult to analyze the results presented. Studies in habitats reported larger numbers of highly susceptible species than those in homogeneous sites or plantations. This scenario of including more suitable species is exploited in practice in China, where 'trap trees' that are more utilized by ALB are included to protect other species. No studies concerning 'trap trees' for CLB were found. Furthermore, Williams et al. (2004) concluded that the varying dynamics of ALB populations across its geographical range may indicate that it is an 'edge specialist' that evolved in riparian habitats. This aspect of understanding the preferred habitat or ecosystem of the beetle was seldom evaluated in the literature reviewed. Instead, the information reported originated from different kinds of plantations with quantitative observations mainly in urban areas of China or North America (Hu et al. 2009; Haack et al. 2010), without further evaluation of ecosystem preferences.

\section{CONCLUSIONS}

The wood-boring Asian longhorned beetle and citrus longhorned beetle may pose serious threats to the tree landscape worldwide since they have many host species and genera. It is therefore important to identify susceptible tree species and genera in order to produce future tree loss scenarios and plan future urban forests (e.g., by selecting less susceptible urban trees). This literature review found many tree species and genera that are liable to be attacked by ALB and CLB, but further information is needed. There is a lack of transparency in published studies listing susceptible tree species for ALB and CLB. It is important to know where and how these studies obtained their information-especially the older studies. Later studies use a much more transparent approach, but more information from the natural environment of the beetles in China and Japan is highly important in understanding why some species and genera are resistant or rarely affected. Another area where more information is needed regarding host trees for ALB and CLB is whether the tree species support the complete life cycle of the beetles or just feeding by adult beetles. An accepted and internationally used conceptual ranking system is needed, describing what exactly makes a tree species a very good host or just a host. Without this system, there is a risk of incorrectly labeling species with moderate host qualities as a very good host and hence banned from use as an urban tree. Another important aspect is to thoroughly evaluate host trees on species level and not include the whole genus, even if many species within the genus are susceptible.

\section{LITERATURE CITED}

Adachi, I. 1994. Development and life cycle of Anoplophora mala siaca (Thomson) (Coleoptera: Cerambycidae) on citrus trees under fluctuating and constant temperature regimes. Applied Entomology and Zoology 29(4):485-497.

APHIS. 2012. USDA-APHIS-PPQ, Center for Plant Health Science and Technology. Asian Longhorned Beetle: Annotated Host List. Accessed 09/26/2012. <www.uvm.edu/albeetle/hosts.htm>

Auclair, A.N.D., G. Fowler, M.K. Hennessey, A.T. Hogue, M. Keena, D.R. Lance, R.M. McDowell, D.O. Oryang, and A.J. Sawyer. 2005. Assessment of the risk of introduction of Anoplophora glabripennis (Coleoptera: Cerambycidae) in municipal solid waste from the quarantine area of New York City landfills outside of the quarantine area: A pathway analysis of the risk of spread and establishment. Journal of Economic Entomology 98(1):47-60.

Bancroft, J.S., M.T. Smith, E.K. Chaput, and J. Tropp. 2002. Rapid test of the suitability of host-trees and the effects of larval history on Anoplophora glabripennis (Coleoptera: Cerambycidae). Journal of the Kansas Entomological Society 75:308-316.

Bao, S., F. Li, Z. Li, and T. Wu. 1999. The resistance of fourteen poplar species to Anoplophora glabripennis (Motsch). Journal of Beijing Forestry University 21:97-100 (Chinese).

CABI. 2007. Crop Protection Compendium. Accessed on 09/26/2012. <www.cabi.org/compendia/cpc>

Cao, C., H. Ma, and H. Wu. 2003. Investigation and assessment on resistance to Anoplophora glabripennis by 17 poplar species. 
Forestry Science and Technology of Inner Mongolia 2:46-48 (Chinese).

Cavey, J.F., E.R. Hoebeke, S. Passoa, and S.W. Lingafelter. 1998. A new exotic threat to North America hardwood forests: An Asian longhorned beetle, Anoplophora glabripennis (Motschulsky) (Coleoptera; Cerambycidae). I. Larval description and diagnosis. Proceeding of the Entomological Society of Washington 100:373-381.

CFIA. 2005. Asian Longhorned Beetle Preferred Host Trees. Canadian Food Inspection Agency. Accessed on 09/26/2012. <http://epe. lac-bac.gc.ca/100/206/301/cfia-acia/2011-09-21/www.inspection.gc.ca/english/plaveg/pestrava/anogla/alhbhostree.shtml>

Chang, S. 1960. New and unrecorded species of longicorn beetles from Taiwan (I). Bulletin of the Society of Plant Pathology and Entomology 11(3/4):1-7.

Chen, F., and F. Wang. 1935. A list of the known fruit insects of China. Year Book of the Bureau of Entomology, Hangchow. Year Book No. 5:82-140 (Chinese).

Cheo, M.T. 1935. A preliminary list of the insects and arachnids injurious to economic plants in China. Peking Natural History Bulletin 10(1):5-37.

Clausen, C.P. 1931. Insect injurious to agriculture in Japan. Circular No. 168. United States Department of Agriculture. 115 pp.

Dodds, K.J., and D.A. Orwig. 2011. An invasive urban forest pest invades natural environments - Asian longhorned beetle in northeast U.S. hardwood forest. Canadian Journal of Forest Research 41(9):1729-1742.

Duffy, E.A.J. 1968. A monograph of the immature stages of Oriental timber beetles (Cerambycidae). British Museum (Natural History), London, England. $434 \mathrm{pp}$.

EPPO. 2012. EPPO Database on Quarantine Pests. European and Mediterranean Plant Protection Organization. Accessed on 09/26/2012. <www.eppo.int/DATABASES/databases.htm>

FAO. 2007. Overview of forest pests in People's Republic of China. Working Paper FBS/13E. Food and Agriculture Organization of the United Nations. Rome, Italy.

Forman, R.T.T., and M. Godron. 1986. Landscape Ecology. Wiley \& Sons, New York City, New York, U.S.

Gao, H.Z., X.Y. Yang, J.N. Wei, and X.R. Lang. 1997. An investigation on the resistance of major forestation species to Anoplophora glabripennis and A. nobilis. Journal of Northwest Forestry College 12:42-46 (Chinese).

Gao, R. 1998. Control over three kinds of ALB by using the adults feeding habit. Beijing Forestry University Journal 20(1):43-48 (Chinese).

Gao, R., and G. Li. 2002. Integrated pest management of poplar fastgrowing and high-yielding plantations. Proceeding, China-U.S. workshop on Asian longhorned beetle Anoplophora glabripennis. June 18-21, 2002, Yinchuan, China. State Forestry Administration, Beijing, China, 2002.

Gao, R., C. Liu, and Y. Lu. 1994. A preliminary study on the causes and use of preference of Apriona germari adults supplementary nutrition for mulberry and papermulberry. Scientia Silvae Sinicae 30(4):376-380 (Chinese).

Gao, R., X. Qin, D. Chen, and W. Chen. 1993. A study on the damage of poplar caused by Anoplophora glabripennis. Forest Research 6:189-193 (Chinese).

Geib, S.M., M.D.M. Jimenez-Gasco, J.E. Carlson, M. Tien, and K. Hoover. 2009. Effect of host tree species on cellulose activity and bacterial community composition in the gut of larval Asian longhorned beetle. Environmental Entomology 38(3):686-699.

Geldof, G.D., and P. Stahre. 2006. On the road to a new stormwater planning approach. Water Practice and Technology 1.

Gine, W., and M.M. Chein. 1986. Forest Diseases and Insect Prevention. Cited in APHIS New Pest Advisory Group (NPAG) report on Asian Longhorned Beetle. From an in-house translation by Millie Yang, CPA, USDA - OIG, provided by Dan Kucera, USDA FS, Radnor, Pennsylvania, U.S. <www.aphis. usda.gov/ppq/bbnpag.html>

Grahn, P., and A.U. Stigsdotter. 2003. Landscape Planning and Stress. Urban Forestry \& Urban Greening 2:1-18.

Gressit, J.L. 1940. Supplement to a study of the longicorn beetle of Kwangtung Province, S. China (Coleoptera: Cerambycidae). Lingnan Science Journal 19:1-20.

Gressit, J.L. 1942. Destructive long-horned beetle borers at Canton, China. Special Publication of Lingnan Natural History Survey Museum 1:1-60.

Gressit, J.L. 1951. Longicorn beetles of China. In: P. Lepesme (Eds.). Longicornia. Volume 2. Paris: Paul Lechevalier. 667 pp.

Guo, B. 1998. The control of Apriona germari (Hope). Anhui Forestry 6:1-15 (Chinese).

Haack, R.A. 2006. Exotic bark- and wood-boring Coleoptera in the United States, recent establishments and interceptions. Canadian Journal of Forest Research 36:269-88.

Haack, R.A., J.F. Cavey, E.R. Hoebeke, and K.R. Law. 1996. Anoplophora glabripennis: A new tree-investing exotic cerambycid invades New York. Newsletter of the Michigan Entomological Society 41(2-3):1-3.

Haack, R.A., J.J. Turgeon, F. Herard, and J. Sun. 2010. Managing invasive populations of Asian longhorned beetle and citrus longhorned beetle: A worldwide perspective. The Annual Review of Entomology 55:521-546.

Haack, R.A., K.R. Law, V.C. Mastro, H.S. Ossenbruggen, and B.J. Raimo. 1997. New York's battle with the Asian long-horned beetle. Journal of Forestry 95(12):11-15.

Haack, R.A., L.S. Bauer, R.T. Gao, J.J. McCarthy, and D.L. Miller. 2006. Anoplophora glabripennis within-tree distribution, seasonal development, and host suitability in China and Chicago. The Great Lakes Entomologist 102:1075-84.

Hajek, A.E., and D.M. Kalb, 2007. Suitability of Acer saccharum and Acer pennsylvanicum (Aceraceae) for rearing Anoplophora glabripennis (Coleoptera: Cerambycidae). The Canadian Entomologist 139(5):751-755.

He, P., and J. Huang. 1993. Adult behavior of Anoplophora glabripennis. Acta Entomologica Sinica 36:51-55 (Chinese).

Hérard, F., M. Ciampitti, M. Maspero, H. Krehan, U. Benker, C. Boegel, R. Schrage, L. Bouhot-Delduc, and P. Bialooki. 2006. Anoplophora species in Europe: Infestations and management processes. EPPO Bulletin 36(3):470-74.

Hérard, F., M. Maspero, N. Ramualde, C. Jucker, M. Colombo, M. Ciampitti, and B. Cavagna. 2009. Anoplophora glabripennis infestation (col.: cerambycidae) in Italy. EPPO Bulletin 39:146-152.

Hu, J., K. Wang, and Y. Han. 1998. Research progress of breeding pest-resistance woody plants. World Forestry Study 1998(3) (Chinese).

Hu, J., S. Angeli, S. Schuetz, Y. Luo, and A.E. Hajek. 2009. Ecology and management of exotic and endemic Asian longhorned beetle Anoplophora glabripennis. Agricultural and Forest Entomology 11:359-375. 
Hua, L. 1982. A checklist of the longicorn beetles of China (Coleoptera: Cerambycidae). Zhongshan University Press, Guangzhou, China. 158 pp (Chinese).

Hua, L., H. Nara, and C. Yu. 1993. Longicorn Beetles of Hainan and Guangdong. Muh-Sheng Museum of Entomology, Nantou Hsien, Taiwan. 320 pp (Chinese).

Jordbruksverket. 2010. Asiatiska långhorningar. Accessed 09/26/2012. <www.jordbruksverket.se/amnesomraden/odling/ vaxtinspektion/vaxtskadegorare/tradochbuskar/asiatiskalangh orningar.4.207049b811dd8a513dc8000782.html>

Keena, M.A. 2002. Anoplohora glabripennis (Coleoptera: Cerambycidae) fecundity and longevity under laboratory conditions: Comparison of populations from New York and Illinois on Acer saccharum. Environmental Entomology 31:490-498.

King, V.J., and C. Davis. 2007. A case study of urban heat island in the Carolinas. Environmental Hazards 7:353-359.

Kojima, K., and M. Hayashi. 1978. Insects' Life in Japan. Volume 1. Longicorn Beetles. Hoikusha Publishing Co, Osaka, Japan. 302 pp (Japanese).

Kojima, K., and M. Nakamura. 1986. Host trees records of Japanese longicorn beetles. Hiba-Kagaku Kyoiku Shinkosha, Shobara.

Kojima, T. 1931. Further investigation on the immature stages of some Japanese Cerambycid beetles, with notes on their habits. Journal of the College of Agriculture of the Imperial University of Tokyo 11:263-308.

Kucera, D. 1996. Risk assessment - Asian long-horned beetle (ALB). USDA Forest Service, State and Private Forestry, Washington, D.C. (unpublished report).

Li, F., R.G. Liu, S. Bao, and T. Wu. 1999. Selection of trap trees for controlling Anoplophora glabripennis and A. Nobilis. Journal of Beijing Forestry University 21:85-89 (Chinese).

Li, J., H. Fan, and Y. Jin. 2003a. Behavior response of Anoplophora glabripennis to the mechanical wounded and herbivore fed ashleaf maple. Journal of Beijing Forestry University 25(5):4246 (Chinese).

Li, S., Z. Zhang, J. Luo, C. He, Y. Pu, and X. An. 2005. Progress and strategies in cross breeding of poplars in China. Forestry Studies in China 7:54-60.

Li, W., and C. Wu. 1993. Integrated management of longhorned beetles damaging poplar trees. China Forest Press, Beijing, China (Chinese).

Li, H., D. Huang, M. Yang, and S. Zhang. 2003b. Selection of Super Poplar Clones with High Resistance to Anoplophora glabripennis. Journal of Northeast Forestry University 31(5) (Chinese).

Lieu, K.V. 1945. The study of wood borers in China. I. Biology and control of the citrus-root cerambycid, Melanuaster chinensis Forster. Florida Entomologist 27:62-101.

Lingafelter, S.W., and E.R. Hoebeke. 2001. Variation and homology in elytral maculation in the Anoplophora malasiaca/macularia species complex (Coleoptera: Cerambycidae) of Japan and Taiwan. Proceeding of the Entomological Society of Washington 103(3):757-769.

Lingafelter, S.W., and E.R. Hoebeke. 2002. Revision of Anoplophora (Coleoptera: Cerambycidae). Entomological Society of Washington, Washington, D.C. 236 pp.

Liu, J., L. Zhou, and H. Song. 2002. Planting trap trees to control Anoplophora glabripennis. Proceedings from a China-U.S. Workshop in Asian Longhorned Beetle, Yinchuan 2002. pp. 46-48 (Chinese).
Ludwig, S.W., L. Lazarus, D.G. McCullough, K. Hoover, S. Montero, and J.C. Sellmer. 2002. Methods to evaluate host tree sustainability to the Asian longhorned beetle, Anoplophora glabripennis. Journal of Environmental Horticulture 20(3):175-180.

Luo, Y., J. Wen, and Z. Xu. 2003. Current situation of research and control on poplar longhorned beetle, especially for Anoplophora glabripennis in China. Nachrichtenbl Deuts Pflanzenschutzd 55:68-70.

MacLeod, A., Evans, H.F., Baker, R.H.A. 2002. An analysis of pest risk from an Asian longhorn beetle (Anoplophora glabripennis) to hardwood trees in the European. Crop Protection 21:635-645.

Maco, S.E., and G. McPherson. 2003. A practical approach to assessing structure, function, and value of street tree population in small communities. Journal of Arboriculture 2984-97.

Maspero, M., C. Jucker, and M. Colombo. 2007. First record of Anoplophora glabripennis (Motschulsky) Coleoptera: Cerambycidae Lamiinae, Lamiini) in Italy. Bolletino di Zoologia Agraria e di Bachicoltura 39:161-164 (Italian).

Mattilsynet, 2012. Norwegian Food Safety Authority. Fact Sheet of Anoplophora chinensis. Accessed 09/26/2012. <www.mattilsynet.no/planter_og_dyrking/planteskadegjorere/citrustrebukk.825>

Morewood, W.D., K. Hoover, P.R. Neiner, and J.C. Sellmer. 2005. Complete development of Anoplophora glabripennis (Coleoptera: Cerambycidae) in northern red oak trees. Canadian Entomologist 137(3):376-379.

Morewood, W.D., K. Hoover, P.R. Neiner, J.R. McNeil, and J.C. Sellmer. 2004a. Host tree resistance against the polyphagous wood-boring beetle Anoplophora glabripennis. Entomologia Experimentalis et Applicata 110(1):79-86.

Morewood, W.D., P.R. Neiner, J.C. Sellmer, and K. Hoover. 2004b. Behavior of adult Anoplophora glabripennis on different tree species under greenhouse conditions. Journal of Insect Behavior 17(2):215-226.

Morewood, W.D., P.R. Neiner, J.R. McNeil, J.C. Sellmer, and K. Hoover. 2003. Oviposition Preference and Larval Performance of Anoplophora glabripennis (Coleoptera: Cerambycidae) in four eastern North American hardwood tree species. Environmental Entomology 32(5):1028-1034.

Natur Erhvervstyrelsen. 2012. The Danish Natural Agency-Minstry of Food, Agriculture and Fisheries in Denmark. Accessed 09/26/2012. <http://agrifish.dk>

Netherlands Plant Protection Service. 2012. Pest Report: Anoplophora chinensis. Accessed 09/26/2012. <www.vwa.nl/onderwerpen/english/dossier/pest-reporting-eng/pest-reports $>$

Nowak, D., D. Crane, and J. Stevens. 2006. Air pollution removal by urban trees and shrubs in the United States. Urban Forestry \& Urban Greening 4:115-123.

Nowak, D.J., J.E. Pasek, R.A. Sequeira, D.E. Crane, and V.C. Mastro. 2001. Potential effect of Anoplophora glabripennis (Coleoptera: Cerambycidae) on urban trees in the United States. Journal of Economic Entomology 94(1):116-122.

Ohga, S., S. Nomura, and S. Inoue. 1995. Survey of basidiomycete and insect infested roadside trees. Bulletin of the Kyushu University Forests 72:203-216.

Qi, X. 1997. Habits of Anoplophora chinensis which causes harm to Casuarina equisetifolia and its control. Forest Research 10:551555 (Chinese).

Qin, X. 1985. Study on resistance to Anoplophora glabripennis of different poplar species. Forestry Science 21(3) (Chinese). 
Qin, X., R. Gao, J. Li, and W. Hao. 1985. Preliminary investigation on the resistance of different clones of poplars to Anoplophora glabripennis (Motsch). Scientia Silvae Sinicae 21:310-314 (Chinese).

Raupp, M.J., A. Buckelew-Cumming, and E.C. Raupp. 2006. Street tree diversity in eastern North America and its potential for tree loss to exotic borers. Arboriculture \& Urban Forestry 32(6):297-304

Ric, J., P. de Groot, B. Gasman, M. Orr, J. Doyle, M.T. Smith, L. Dumouchel, T. Scarr, and J.J. Turgeon. 2006. Detecting signs and symptoms of Asian longhorned beetle injury. Natural Resources Canada, Canadian Forest Service, and Canadian Food Inspection Agency. 121 pp.

Sæbø, A., B. Zelimir, C. Ducatillion, A. Hatzistathis, T. Lagerström, J. Supuka, J.L. Garcis Valdecantos, F. Rego, and J. Slycken. 2005. The selection of plant materials for street trees, park trees and urban woodlands. In: C.C. Konijnendijk, K. Nilsson, T.B. Randrup, and J. Schipperijn (Eds.). Urban Forests and Trees. pp. 257-280. Springer. G.A. Samuelson. 1965. The Cerambycidae (Coleopt.) of the Ryukya Archippelago II. Lamiinae. Pacific Insects 7:82-130.

Shao, Q., R. Tian, and P. Gao. 1997. Study on the trap trees to control A. glabripennis and its function. Inner Mongolia Science \& Technology 4:12-24 (Chinese).

Sjöman, H., A. Gunnarsson, S. Pauleit, and R. Bothmer. 2012b. Selection approach of urban trees for inner-city environments: Learning from nature. Arboriculture \& Urban Forestry 38(5):194-204

Sjöman, H., J. Östberg, and O. Bühler. 2012a. Diversity and distribution of the urban tree population in ten major Nordic cities. Urban Forestry \& Urban Greening 11:31-39.

Smith, M.T., J. Bancroft, and J. Tropp. 2002. Age-specific fecundity of Anoplophora glabripennis (Coleoptera: Cerambycida) on three tree species infested in United States. Environmental Entomology 31:76-83.

Smith, M.T., J.J. Turgeron, P. de Groot, and B. Gasman. 2009. Asian longhorned beetle Anoplophora glabripennis (Motschulsky): Lessons learned and opportunities to improve the process of eradication and management. American Entomologist 55:21-25.

Sun, J.Z., Z. Zhao, and T. Ru. 1990b. Plant chinaberry and hard maple as trap trees to control Anoplophora glabripennis. Forest Pest 2:10-12 (Chinese).

Sun, J.Z., Z.Y. Zhao, T.Q. Ru, Z.G. Qian, and X.J. Song. 1990a. Control of Anoplophora glabripennis by using cultural methods. Forest Pest and Disease 2:10-12 (Chinese).

Sun, W. 1995. The control of Apriona germari (Hope) on poplar. China Forestry 7:10-12 (Chinese).

Tian, R., J. Yu, and W. Zhao. 2003. On the function of Elaeagnus angustifolia L. to induce and control Anoplophora glabripennis (Motsch.). Inner Mongolia Forestry Science \& Technology 4:23-25 (Chinese)

Tomiczek, C., and U. Hoyer-Tomiczek. 2007. Der asiatische laubholzbockkäfer (Anoplophora glabripennis) und der citrusbockkäfer (Anoplophora chinensis) in europa-ein situationsbericht. Forstschultz Aktuell 38:2-5 (German).

Tyrväinen, L., L. Mäkinen, and J. Schipperijn. 2005. Tools for mapping social values for urban woodlands and of other green spaces. Landscape and Urban Planning 79(1):5-19.

Van der Gaag, D.J., G. Sinatra, P.F. Roversi, A. Loomans, F. Hérard, and A. Vukadin. 2010. Evaluation of eradication measures against Anoplophora chinensis in early stage infestations in Europe. EPPO Bulletin 40:176-187.

Van der Gaag, D.J., M. Ciampitti, B. Cavagna, M. Maspero, and F. Hérard. 2008. Pest risk analysis: Anoplophora chinensis. Plant Protection Service, Wageningen, The Netherlands. 49 pp.

Vukadin, A., and B. Hrasovec. 2008. Anoplophora chinensis (Forster) in Croatia. Forstschutz Aktuell 44.

Wang, B., V. Mastro, and R. Gao. 2005. Host range of Anoplophora glabripennis: What we've learned from common-garden experiment data. In the proceeding of the 16th U.S. Department of Agriculture interagency research forum on gypsy moth and other invasive species 2005. pp. 89. USDA Forestry Service.

Wang, Q., L.Y. Chen, W.Y. Zeng, and J.S. Li. 1996. Reproductive behavior of Anoplophora chinensis (Forster) (Coleoptera: Cerambycidae: Lamiinae), a serious pest of citrus. The Entomologist 115:40-49.

Wang, R. 1993. Study on resistance of P. $\times$ euroamericana 'I-69' and $P$. dakuanensis 'Daguan' to ALB. Beijing Forestry University Journal 15(1):85-90 (Chinese).

Wang, T.Z., and D.P. Chen. 1984. Notes on the damage done by Anoplophora chinensis to Cryptomeria japonica. Forest Science and Technology Liney Keji Tongxun 6:26-27 (Chinese).

Wang, X., W. Lu, and Z. Zhang. 1987. The resistance of the poplar species to the harmful effect of Anoplophora nobilis Ganglpauer. Scientia Silvae Sinicae 1987-01 (Chinese).

Wang, Z.G. 2004. Study on the occurrence dynamics of Anoplophora glabripennis (Coleoptera: Cerambycidae) and its control measures. Ph.D. thesis. Northeast Forestry University Harbin, China. pp. 98 (Chinese).

Wen, J., Y. Luo, and J. Yue. 1999. The attracting effect of Acer negundo Linn. on A. glabripennis (Motsch) adults. Forest Pest and Disease 4:17-20 (Chinese).

Williams, D.W., H-P. Lee, and I-K. Kim. 2004. Distribution and abundance of Anoplophora glabripennis (Coleoptera: Cerambycidae) in natural Acer stands in South Korea. Environmental Entomology 33(3):540-545.

Wright, R.W., R.A. Brand, W. Dunn, and K.P. Spindler. 2007. How to write a systematic review. Clinical Orthopaedics and Related Research 455:23-29.

Wu, W., and S. Chiang. 1998. The glabripennis species group of the genus Anoplophora in China (Coleoptera: Cerambycidae). Acta Entomologica Sinica 41:284-290 (Chinese).

Xiao, G. 1992. Forest Insects of China. 2nd Edition. China Forestry Press, Beijing, China. 1362 pp (Chinese).

Yan, Y.H., D.Z. Huang, and J.J. Yan. 1996. A preliminary study on the relationship between amino acid composition in wood and susceptibility to Anoplophora glabripennis for several species in Salicaceae. Journal of Hebei Forestry College 11:259-262 (Chinese).

Yang, P.H. 2005. Review of the Asian Longhorned Beetle Research, Biology, Distribution, and Management in China, Forest Health \& Biosecurity Working Papers FBS/6E. Forest Resources Development Service, Forest Resources Division, FAO, Rome.

Yang, X. 2003. Relation between ALB severity and stands' structure. Journal of Forestry Science and Technology of Gansu 28:3 (Chinese)

Yang, X., J. Zhou, F. Wang, and M. Cui. 1995. A study on the feeding habits of the larvae of two species of longhorn (Anoplophora) to different tree species. Journal of the Northwest Forestry College, China 10(2):1-6 (Chinese). 
Yin, W., and W. Lu. 2005. Review of Tree Selection and Afforestation for Control of Asian Longhorned Beetle in North China. Food \& Agriculture Organization, Forestry Department. FAO Rome. Accessed 09/26/2012. <www.fao.org/forestry/9599058fddfef27dd6c45f4665cedfcb9648f.pdf>

Zhang, E., J. Zhou, and R. Liu. 1995. Investigation on ALB damage to shelterbelts in Ningxia and stands' structure arrangement. Northwest Forestry College Journal 10(2):16-21 (Chinese).

Zhang, Y., and Q. Lu. 2003. Reflection on control measures for Anoplophora glabripennis. Forestry Science and Technology of Inner Mongolia 1(1) (Chinese).

Zhao, T.H., W.X. Gao, R.T. Zhang, Q.W. Li, X.X. Liu. 2007. Induced outbreaks of indigenous insect species by exotic tree species. Acta Entomologica Sinica 50:826-833 (Chinese).

Zhou, J.X. 1984. Behavior of adults of Anoplophora nobilis Ganglpauer and their selection of woody species. Northwest Forestry College Journal 1(1):119-127 (Chinese).

Zhou, J.X., M.T. Liu, Y.Z. Lu, and X. Yang. 1981. A preliminary study on Anoplophora nobilis Ganglbauer (Coleoptera: Cerambycidae). Scientia Silvae Sinicae 17(4):413-418 (Chinese).

Henrik Sjöman (corresponding author)

Swedish University of Agricultural Sciences

Faculty of Landscape Planning

Horticulture and Agricultural Science

Department of Landscape Architecture, Planning and Management Box 66, SE-23053

Alnarp, Sweden

henrik.sjoman@slu.se

Johan Östberg

Swedish University of Agricultural Sciences

Faculty of Landscape Planning

Horticulture and Agricultural Science

Department of Landscape Architecture, Planning and Management Box 66, SE-23053

Alnarp, Sweden

johan.ostberg@slu.se

Johan Nilsson

Swedish University of Agricultural Sciences

Faculty of Landscape Planning

Horticulture and Agricultural Science

Department of Landscape Architecture, Planning and Management

Box 66, SE-23053

Alnarp, Sweden
Zusammenfassung. Zwei verheerend wirkende Schadinsekten sind nach Nordamerika und Europa eingeschleppt worden: der Asiatische Laubholzbock und der Zitrusbock. Diese beiden holzbohrenden Insekten werden als größte Gefahr für unsere Baumlandschaft betrachtet, da sie ein großes Wirtsspektrum von Arten und Gattungen haben. Mit dem Versuch, eine aktuelle Zusammenstellung dieser Wirte zu kreieren, wurde eine systematische Übersicht über die Literatur mit Informationen zu den mit den beiden Laubbockkäfern befallenen Arten, die den Käfern für ihren gesamten Lebenszyklus als Wirt dienten oder als Fraßquelle genutzt wurden. Diese Übersicht enthüllte, dass eine sehr große Anzahl von Arten und Gattungen von diesen Käfern attackiert und gefressen werden. Dennoch bleibt der Eindruck nach diesen Ergebnissen unklar. Ein Grund dafür liegt in diesem Mangel an Transparenz in den veröffentlichen Studien bezüglich der bevorzugten Baumarten dieser beiden Käfer. Ein anderer Faktor, der erwähnt werden müsste, ist der Umstand, ob der Baum den ganzen Entwicklungsprozess des Bockkäfers unterstützt oder ob der nur von adulten Insekten gefressen wird. Ohne diese Informationen können Bäume mit nur moderaten Wirtseigenschaften als solche mit hervorragenden Wirtseigenschaften gekennzeichnet und somit als geeigneter Stadtbaum ausgeschlossen werden.

Resumen. Dos devastadoras plagas de insectos se han introducido en América del Norte y Europa - el escarabajo asiático de cuernos largos (ALB ) (Anoplophora glabripennis) y los escarabajos cítricos (CLB ) (Anoplophora chinensis). Estos dos escarabajos perforadores de la madera se argumentan ser una de las amenazas más graves para los árboles urbanos, ya que tienen un gran número de especies y géneros hospederos. Con el objetivo de crear una compilación actualizada de estos hospederos, se hizo una revisión sistemática de la literatura para obtener información sobre las especies de árboles atacados y utilizados por ALB y CLB como anfitriones para completar el ciclo de vida o para la alimentación. Esta revisión reveló que un gran número de especies de árboles y géneros son susceptibles de ser atacados por ALB y CLB. Sin embargo, con base en los resultados, el panorama aún es poco claro. Una razón de esto es la falta de transparencia en los estudios publicados con respecto a las listas de especies arbóreas susceptibles de ALB y CLB. Otro factor que debe ser reportado es si una especie de árbol soporta el ciclo de vida completo de los escarabajos o simplemente alimenta a los adultos. Sin esta información, las especies que poseen cualidades moderadas de hospedaje están en riesgo de ser etiquetados incorrectamente como muy buenos hospederos y por lo tanto excluidos como árboles urbanos. 


\section{APPENDIX 1. Species/genera host grades for ALB according to the literature.}

Full development means that a full beetle development can take place or that exit holes are present. Feeding means that the adult beetles feed on the tree species but there is no claim that full development can take place or that exit holes are present. No information means that there is no information on the type of development or investment is present.

This appendix is based on the following articles: Haack et al. 1997; Nowak et al. 2001; Lingafelter and Hoebeke 2002; Ludwig et al. 2002; MacLeod et al. 2002; Smith et al. 2002; Morewood et al. 2003; Morewood et al. 2004a; Morewood et al. 2004b; Williams et al. 2004a; Auclair et al. 2005; CFIA 2005; Morewood et al. 2005; Weilun and Wen 2005; Yang 2005; Hérard et al. 2006; Raupp et al. 2006; Ric et al. 2006; FAO 2007; Hajek and Kalb 2007; Geib et al. 2009; Natur Erhvervstyrelsen 2008; Hérard et al. 2009; Hu et al. 2009; Haack et al. 2010; Jordbruksverket 2010; APHIS 2011; Dodds et al. 2011; EPPO 2012.

${ }^{z}$ A detailed description of the Populus genus is given in Table 2.

\begin{tabular}{|c|c|c|c|c|c|c|c|c|}
\hline \multirow[b]{2}{*}{ Species } & \multirow[b]{2}{*}{$\begin{array}{l}\text { Total number } \\
\text { of studies }\end{array}$} & \multicolumn{4}{|c|}{ Numbers of articles } & \multicolumn{3}{|c|}{ Type of development } \\
\hline & & $\begin{array}{l}\text { Resistant/ } \\
\text { resilient }\end{array}$ & Host & $\begin{array}{l}\text { Good } \\
\text { host }\end{array}$ & $\begin{array}{l}\text { Very good } \\
\text { host }\end{array}$ & $\begin{array}{l}\text { Full } \\
\text { development }\end{array}$ & Feeding & $\begin{array}{l}\text { No } \\
\text { information }\end{array}$ \\
\hline Acer buergerianum & 3 & 1 & & & 2 & 1 & & 1 \\
\hline Acer ginnala & 2 & 2 & & & & & & 1 \\
\hline Acer mono & 3 & & & 1 & 2 & 2 & & 1 \\
\hline Acer negundo & 9 & & 3 & & 6 & 1 & & 8 \\
\hline Acer palmatum & 2 & 2 & & & & & & 1 \\
\hline Acer pensylvanicum & 2 & & 1 & 1 & & 1 & 1 & \\
\hline Acer platanoides & 13 & & 5 & 2 & 6 & 6 & & 7 \\
\hline Acerpseudoplatanus & 8 & & 4 & 2 & 2 & 2 & & 6 \\
\hline Acer pseudosieboldianum & 1 & & & 1 & & & & 1 \\
\hline Acer rubrum & 7 & & 2 & 1 & 4 & 4 & & 3 \\
\hline Acer saccharinum & 7 & & 4 & 1 & 2 & 1 & & 6 \\
\hline Acer saccharum & 11 & & 4 & & 7 & 4 & 1 & 7 \\
\hline Acer spp. & 18 & & 6 & 1 & 11 & 4 & 1 & 13 \\
\hline Acer tegmentosum & 1 & & & 1 & & & & 1 \\
\hline Acer triflorum & 1 & 1 & & & & & & \\
\hline Acer truncatum & 3 & & & 1 & 2 & 1 & & 2 \\
\hline Aesculus hippocastanum & 6 & & 3 & 2 & 1 & 1 & & 5 \\
\hline Aesculus ssp. & 10 & & 4 & 3 & 3 & 3 & 1 & 6 \\
\hline Ailanthus altissima & 4 & 4 & & & & & & \\
\hline Albizia spp. & 8 & 2 & 4 & 1 & 1 & 4 & & 2 \\
\hline Alnus spp. & 7 & 2 & 4 & 1 & & 2 & 1 & 2 \\
\hline Amelanchier spp. & 1 & 1 & & & & & & \\
\hline Betula nigra & 2 & & & & 2 & 1 & & 1 \\
\hline Betula pendula & 2 & & 2 & & & 1 & & 1 \\
\hline Betula spp. & 13 & & 5 & 6 & 2 & 5 & & 8 \\
\hline Broussonetia papyrifera & 3 & 2 & & 1 & & & & 1 \\
\hline Carpinus betulus & 1 & & 1 & & & & & 1 \\
\hline Carpinus spp. & 2 & 1 & & 1 & & 1 & & \\
\hline Carya spp. & 1 & 1 & & & & & & \\
\hline Catalpa bungei & 2 & 2 & & & & & & \\
\hline Celtis spp. & 5 & & 4 & 1 & & 2 & & 3 \\
\hline Cercidiphyllum spp. & 2 & & 1 & 1 & & 1 & & 1 \\
\hline Cercis chinensis & 2 & 2 & & & & & & \\
\hline Cercis spp. & 1 & 1 & & & & & & \\
\hline Corylus spp. & 1 & 1 & & & & & & \\
\hline Crataegus pinnatifida & 1 & 1 & & & & & & \\
\hline Crataegus spp. & 1 & 1 & & & & & & \\
\hline Diospyros kaki & 1 & 1 & & & & & & \\
\hline Elaeagnus angustifolia & 2 & & 1 & 1 & & 1 & & 1 \\
\hline Elaeagnus spp. & 6 & 1 & 3 & 1 & 1 & 3 & 1 & 1 \\
\hline
\end{tabular}




\begin{tabular}{|c|c|c|c|c|c|c|c|c|}
\hline \multirow[b]{2}{*}{ Species } & \multirow[b]{2}{*}{$\begin{array}{l}\text { Total number } \\
\text { of studies }\end{array}$} & \multicolumn{4}{|c|}{ Numbers of articles } & \multicolumn{3}{|c|}{ Type of development } \\
\hline & & $\begin{array}{l}\text { Resistant/ } \\
\text { resilient }\end{array}$ & Host & $\begin{array}{l}\text { Good } \\
\text { host }\end{array}$ & $\begin{array}{l}\text { Very good } \\
\text { host }\end{array}$ & $\begin{array}{l}\text { Full } \\
\text { development }\end{array}$ & Feeding & $\begin{array}{l}\text { No } \\
\text { information }\end{array}$ \\
\hline Eucommia ulmoides & 1 & 1 & & & & & & \\
\hline Euonymus spp. & 1 & 1 & & & & & & \\
\hline Fagus spp. & 3 & 2 & & 1 & & 1 & & \\
\hline Fagus sylvatica & 2 & & 2 & & & & & 2 \\
\hline Fraxinus americana & 2 & 2 & & & & & & \\
\hline Fraxinus mandshurica & 2 & 2 & & & & & & \\
\hline Fraxinus pennsylvanicum & 3 & & 3 & & & 1 & & 2 \\
\hline Fraxinus sogdiana & 2 & 2 & & & & & & \\
\hline Fraxinus spp. & 10 & & 8 & 2 & & 3 & 1 & 6 \\
\hline Gleditsia spp. & 2 & 1 & 1 & & & 1 & & \\
\hline Gleditsia triacanthos & 1 & 1 & & & & & & \\
\hline Gingko biloba & 1 & 1 & & & & & & \\
\hline Gymnocladus spp. & 1 & 1 & & & & & & \\
\hline Hamamelis spp. & 1 & 1 & & & & & & \\
\hline Hedysarum spp. & 1 & & 1 & & & & & 1 \\
\hline Hibiscus spp. & 7 & 3 & 3 & 1 & & 1 & & 3 \\
\hline Hippophae spp. & 1 & & 1 & & & & & 1 \\
\hline Juglans regia & 1 & 1 & & & & & & \\
\hline Juglans spp. & 1 & 1 & & & & & & \\
\hline Koelreuteria spp. & 4 & 2 & 1 & & 1 & & & 2 \\
\hline Liquidambar styraciflua & 1 & 1 & & & & & & \\
\hline Liriodendron chinensis & 1 & 1 & & & & & & \\
\hline Liriodendron tulipifera & 4 & 3 & 1 & & & & & 1 \\
\hline Magnolia denudata & 1 & 1 & & & & & & \\
\hline Magnolia spp. & 1 & 1 & & & & & & \\
\hline Malus pumila & 2 & 1 & 1 & & & & & 1 \\
\hline Malus spp. & 6 & 1 & 5 & & & 1 & 1 & 3 \\
\hline Melia spp. & 6 & 2 & 3 & 1 & & & 1 & 3 \\
\hline Melia azedarach & 2 & 1 & 1 & & & & & 1 \\
\hline Metasequoia glyptostroboides & 1 & 1 & & & & & & \\
\hline Morus spp. & 8 & 2 & 5 & 1 & & & 2 & 4 \\
\hline Morus alba & 4 & 1 & 3 & & & & & 3 \\
\hline Ostrya spp. & 1 & 1 & & & & & & \\
\hline Pinus spp. & 1 & 1 & & & & & & \\
\hline Platanus $\times$ hispanica & 1 & 1 & & & & & & \\
\hline Platanus occidentalis & 1 & 1 & & & & & & \\
\hline Paulownia tomentosa & 1 & 1 & & & & & & \\
\hline Platanus spp. & 15 & 2 & 6 & 7 & & 5 & & 8 \\
\hline Populus spp. ${ }^{\mathrm{z}}$ & 19 & & 8 & 2 & 9 & 7 & & 12 \\
\hline Prunus armeniaca & 1 & 1 & & & & & & \\
\hline Prunus cerasifera & 1 & 1 & & & & & & \\
\hline Prunus salicina & 1 & & 1 & & & & & 1 \\
\hline Prunus spp. & 13 & 2 & 9 & 2 & & 2 & 1 & 8 \\
\hline Punica granatum & 1 & 1 & & & & & & \\
\hline Pyrus calleryana & 4 & 4 & & & & & & \\
\hline Pyrus spp. & 9 & 2 & 6 & 1 & & 1 & & 6 \\
\hline Quercus alba & 1 & & & 1 & & 1 & & \\
\hline Quercus liaotungensis & 1 & 1 & & & & & & \\
\hline Quercus palustris & 1 & & 1 & & & & & 1 \\
\hline Quercus rubra & 4 & & 3 & 1 & & 3 & & 1 \\
\hline Quercus spp. & 8 & 7 & 1 & & & & 1 & \\
\hline Rhus typhina & 1 & 1 & & & & & & \\
\hline Rhamnus spp. & 1 & 1 & & & & & & \\
\hline Robinia pseudoacacia & 5 & 2 & 3 & & & & & 3 \\
\hline Robinia spp. & 6 & 2 & 3 & 1 & & & 1 & 3 \\
\hline
\end{tabular}




\begin{tabular}{|c|c|c|c|c|c|c|c|c|}
\hline \multirow[b]{2}{*}{ Species } & \multirow[b]{2}{*}{$\begin{array}{l}\text { Total number } \\
\text { of studies }\end{array}$} & \multicolumn{4}{|c|}{ Numbers of articles } & \multicolumn{3}{|c|}{ Type of development } \\
\hline & & $\begin{array}{l}\text { Resistant/ } \\
\text { resilient }\end{array}$ & Host & $\begin{array}{l}\text { Good } \\
\text { host }\end{array}$ & $\begin{array}{l}\text { Very good } \\
\text { host }\end{array}$ & $\begin{array}{l}\text { Full } \\
\text { development }\end{array}$ & Feeding & $\begin{array}{l}\text { No } \\
\text { information }\end{array}$ \\
\hline Rosa spp. & 2 & & 2 & & & & & 2 \\
\hline Salix babylonica & 2 & & & & 2 & 1 & & 1 \\
\hline Salix matsudana & 3 & & 1 & & 2 & 1 & & 2 \\
\hline Salix nigra & 1 & & 1 & & & 1 & & \\
\hline Salix spp. & 18 & & 5 & 2 & 11 & 6 & 1 & 11 \\
\hline Sambucus spp. & 1 & 1 & & & & & & \\
\hline Sophora japonica & 1 & 1 & & & & & & \\
\hline Sophora ssp. & 3 & & 3 & & & & 1 & 2 \\
\hline Sorbus spp. & 6 & & 4 & 2 & & 3 & & 3 \\
\hline Syringa spp. & 1 & 1 & & & & & & \\
\hline Tilia paucicostata & 1 & 1 & & & & & & \\
\hline Tilia spp. & 7 & 2 & 5 & & & & 2 & 3 \\
\hline Toona sinensis & 1 & 1 & & & & & & \\
\hline Toxicodendron vernicifluum & 1 & 1 & & & & & & \\
\hline Ulmus americana & 1 & & 1 & & & 1 & & \\
\hline Ulmus pumila & 3 & & 1 & & 2 & 2 & & 1 \\
\hline Ulmus spp. & 16 & & 6 & 2 & 8 & 4 & 1 & 11 \\
\hline Vitis vinifera & 1 & & 1 & & & 1 & & \\
\hline Viburnum spp. & 1 & 1 & & & & & & \\
\hline
\end{tabular}




\section{APPENDIX 2. Species/genera host grades for CLB according to the literature.}

Full development means that a full beetle development can take place or that exit holes are present. Feeding means that the adult beetles feed on the tree species but there is no claim that full development can take place or that exit holes are present. No information means that there is no information on the type of development or investment is present.

This appendix is based on the following articles: Adachi 1994; Lingafelter and Hoebeke, 2001; Lingafelter and Hoebeke 2002; Hérard et al. 2006; Natur Erhvervstyrelsen 2008; van der Gaag et al. 2008; Vukadin and Hrasovec 2008; Haack et al. 2010; Jordbruksverket 2010; van der Gaag et al. 2010; EPPO 2012; Mattilsynet 2012; Netherlands Plant Protection Service 2012.

\begin{tabular}{|c|c|c|c|c|c|c|c|c|}
\hline \multirow[b]{2}{*}{ Species } & \multirow[b]{2}{*}{$\begin{array}{l}\text { Total number } \\
\text { of studies }\end{array}$} & \multicolumn{4}{|c|}{ Numbers of articles } & \multicolumn{3}{|c|}{ Type of development } \\
\hline & & $\begin{array}{l}\text { Resistant/ } \\
\text { resilient }\end{array}$ & Host & $\begin{array}{l}\text { Good } \\
\text { host }\end{array}$ & $\begin{array}{l}\text { Very good } \\
\text { host }\end{array}$ & Full & $\begin{array}{l}\text { Feeding } \\
\text { development }\end{array}$ & $\begin{array}{l}\text { No } \\
\text { information }\end{array}$ \\
\hline Acacia decurrens & 1 & & 1 & & & & & 1 \\
\hline Acacia spp. & 2 & & 2 & & & 1 & & 1 \\
\hline Acer campestre & 2 & & 2 & & & 2 & & \\
\hline Acer mono & 1 & & 1 & & & & & 1 \\
\hline Acer negundo & 3 & & 3 & & & 1 & & 2 \\
\hline Acer oblongum & 1 & & 1 & & & & & 1 \\
\hline Acer palmatum & 3 & & 2 & 1 & & 3 & & 1 \\
\hline Acer platanoides & 3 & & 3 & & & 2 & & 1 \\
\hline Acerpseudoplatanus & 3 & & 3 & & & 2 & & 1 \\
\hline Acer saccharinum & 2 & & 1 & 1 & & 1 & & 1 \\
\hline Acer spp. & 11 & & 8 & & 3 & 3 & & 8 \\
\hline Aesculus hippocastanum & 4 & & 4 & & & 1 & & 3 \\
\hline Aesculus ssp. & 2 & & 1 & 1 & & 1 & & 1 \\
\hline Albizia julibrissin & 1 & & 1 & & & & & 1 \\
\hline Albizia spp. & 1 & & 1 & & & & & 1 \\
\hline Aleurites fordii & 1 & & 1 & & & & & 1 \\
\hline Aleurites spp. & 1 & & 1 & & & & & 1 \\
\hline Alnus crispa subsp. Maximowiczii & 1 & & 1 & & & & & 1 \\
\hline Alnus firma & 1 & & 1 & & & & & 1 \\
\hline Alnus hirsuta & 1 & & 1 & & & & & 1 \\
\hline Alnus pendula & 1 & & 1 & & & & & 1 \\
\hline Alnus sieboldiana & 1 & & 1 & & & & & 1 \\
\hline Alnus spp. & 6 & & 5 & 1 & & 1 & & 5 \\
\hline Aralia cordata & 1 & & 1 & & & & & 1 \\
\hline Aralia spp. & 1 & & 1 & & & & & 1 \\
\hline Atalantia buxifolia & 1 & & 1 & & & & & 1 \\
\hline Atalantia spp. & 1 & & 1 & & & & & 1 \\
\hline Betula pendula & 1 & & 1 & & & & & 1 \\
\hline Betula platyphylla & 1 & & 1 & & & & & 1 \\
\hline Betula spp. & 7 & & 6 & & 1 & 1 & & 6 \\
\hline Broussonetia papyrifera & 1 & & 1 & & & & & 1 \\
\hline Broussonetia spp. & 1 & & 1 & & & & & 1 \\
\hline Cajanus cajan & 1 & & 1 & & & & & 1 \\
\hline Cajanus spp. & 1 & & 1 & & & & & 1 \\
\hline Camellia oleifera & 1 & & 1 & & & & & 1 \\
\hline Camellia spp. & 1 & & 1 & & & & & 1 \\
\hline Carpinus betulus & 1 & & 1 & & & & & 1 \\
\hline Carpinus laxiflora & 2 & & 2 & & & 1 & & 1 \\
\hline Carpinus spp. & 5 & & 4 & 1 & & 1 & & 4 \\
\hline Carya illinoensis & 1 & & 1 & & & & & 1 \\
\hline Carya spp. & 1 & & 1 & & & & & 1 \\
\hline Castanea crenata & 1 & & 1 & & & & & 1 \\
\hline Castanea spp. & 1 & & 1 & & & & & \\
\hline
\end{tabular}




\begin{tabular}{|c|c|c|c|c|c|c|c|c|}
\hline \multirow[b]{2}{*}{ Species } & \multirow[b]{2}{*}{$\begin{array}{l}\text { Total number } \\
\text { of studies }\end{array}$} & \multicolumn{4}{|c|}{ Numbers of articles } & \multicolumn{3}{|c|}{ Type of development } \\
\hline & & $\begin{array}{l}\text { Resistant/ } \\
\text { resilient }\end{array}$ & Host & $\begin{array}{l}\text { Good } \\
\text { host }\end{array}$ & $\begin{array}{l}\text { Very good } \\
\text { host }\end{array}$ & $\overline{\text { Full }}$ & $\begin{array}{l}\text { Feeding } \\
\text { development }\end{array}$ & $\begin{array}{l}\text { No } \\
\text { information }\end{array}$ \\
\hline Castanopsis cuspidata var. sieboldii & 1 & & 1 & & & & & 1 \\
\hline Castanopsis spp. & 1 & & 1 & & & & & 1 \\
\hline Casuarina equisetifolia & 1 & & 1 & & & & & 1 \\
\hline Casuarina spp. & 1 & & 1 & & & & & 1 \\
\hline Casuarina stricta & 1 & & 1 & & & & & 1 \\
\hline Catalpa spp. & 1 & & 1 & & & & & 1 \\
\hline Cercis spp. & 1 & & 1 & & & & & 1 \\
\hline Chaenomeles spp. & 2 & & 2 & & & & & 2 \\
\hline Citrus aurantifolia & 1 & & 1 & & & & & 1 \\
\hline Citrus aurantium & 1 & & 1 & & & & & 1 \\
\hline Citrus grandis & 1 & & 1 & & & & & 1 \\
\hline Citrus limonia & 1 & & 1 & & & & & 1 \\
\hline Citrus maxima & 1 & & 1 & & & & & 1 \\
\hline Citrus nobilis & 1 & & 1 & & & & & 1 \\
\hline Citrus sinensis & 1 & & 1 & & & & & 1 \\
\hline Citrus spp. & 9 & & 5 & 2 & 2 & 5 & & 4 \\
\hline Cornus spp. & 3 & & 2 & 1 & & 1 & & 2 \\
\hline Corylus avellana & 2 & & 2 & & & 1 & & \\
\hline Corylus spp. & 7 & & 6 & & 1 & 1 & & 6 \\
\hline Cotoneaster spp. & 5 & & 4 & 1 & & 1 & & 4 \\
\hline Crataegus spp. & 5 & & 4 & 1 & & 2 & & 3 \\
\hline Cryptomeria japonica & 1 & & 1 & & & & & 1 \\
\hline Cryptomeria spp. & 5 & & 5 & & & 1 & & 4 \\
\hline Cydonia sinensis & & & & & & & & \\
\hline Eleagnus multiflora & 1 & & 1 & & & & & 1 \\
\hline Eleagnus spp. & 2 & & 2 & & & & & 2 \\
\hline Eleagnus umbellata & 1 & & 1 & & & & & 1 \\
\hline Eriobotrya japonica & 1 & & 1 & & & & & 1 \\
\hline Eriobotrya spp. & 2 & & 2 & & & & 1 & 1 \\
\hline Fagus crenata & 1 & & 1 & & & & & 1 \\
\hline Fagus spp. & 6 & & 5 & 1 & & 1 & & 5 \\
\hline Fagus sylvatica & 1 & & 1 & & & & & 1 \\
\hline Ficus carica & 2 & & 2 & & & & & 2 \\
\hline Ficus spp. & 4 & & 4 & & & & 1 & 3 \\
\hline Fortunella marginata & 1 & & 1 & & & & & 1 \\
\hline Fortunella spp. & 1 & & 1 & & & & & 1 \\
\hline Fraxinus americana & 1 & & 1 & & & & & 1 \\
\hline Fraxinus spp. & 1 & & 1 & & & & & 1 \\
\hline Grevillea spp. & 1 & & 1 & & & & & 1 \\
\hline Hedera rhombea & 1 & & 1 & & & & & 1 \\
\hline Hedera spp. & 1 & & 1 & & & & & 1 \\
\hline Hibiscus mutabilis & 1 & & 1 & & & & & 1 \\
\hline Hibiscus spp. & 3 & & 3 & & & & & 3 \\
\hline Ilex chinensis & 1 & & 1 & & & & & 1 \\
\hline Ilex spp. & 1 & & 1 & & & & & 1 \\
\hline Juglans mandshurica & 1 & & 1 & & & & & 1 \\
\hline Juglans spp. & 1 & & 1 & & & & & 1 \\
\hline Lagerstroemia indica & 1 & & 1 & & & & & 1 \\
\hline Lagerstroemia spp. & 6 & & 4 & 1 & 1 & 3 & & 3 \\
\hline Lindera praecox & 1 & & 1 & & & & & 1 \\
\hline Lindera spp. & 1 & & 1 & & & & & 1 \\
\hline Litchi sinensis & 1 & & 1 & & & & & 1 \\
\hline Litchi spp. & 1 & & 1 & & & & & 1 \\
\hline Liquidambar spp. & 2 & & 1 & 1 & & 1 & & 1 \\
\hline Maakia amurensis subsp. buergeri & 1 & & 1 & & & & & 1 \\
\hline
\end{tabular}




\begin{tabular}{|c|c|c|c|c|c|c|c|c|}
\hline \multirow[b]{2}{*}{ Species } & \multirow[b]{2}{*}{$\begin{array}{l}\text { Total number } \\
\text { of studies }\end{array}$} & \multicolumn{4}{|c|}{ Numbers of articles } & \multicolumn{3}{|c|}{ Type of development } \\
\hline & & $\begin{array}{l}\text { Resistant/ } \\
\text { resilient }\end{array}$ & Host & $\begin{array}{l}\text { Good } \\
\text { host }\end{array}$ & $\begin{array}{l}\text { Very good } \\
\text { host }\end{array}$ & $\overline{\text { Full }}$ & $\begin{array}{l}\text { Feeding } \\
\text { development }\end{array}$ & $\begin{array}{l}\text { No } \\
\text { information }\end{array}$ \\
\hline Maakia spp. & 1 & & 1 & & & & & 1 \\
\hline Mallotus japonicus & 1 & & 1 & & & & & 1 \\
\hline Mallotus spp. & 1 & & 1 & & & & & 1 \\
\hline Malus asiatica & 1 & & 1 & & & & & 1 \\
\hline Malus pumila & 1 & & 1 & & & & & 1 \\
\hline Malus spp. & 10 & & 8 & 1 & 1 & 1 & & 9 \\
\hline Malus sylvestris & 1 & & 1 & & & & 1 & \\
\hline Melia azedarach var. subtripinnata & 1 & & 1 & & & & & 1 \\
\hline Melia japonica & 1 & & 1 & & & & & 1 \\
\hline Melia spp. & 1 & & 1 & & & & & 1 \\
\hline Morus alba & 1 & & 1 & & & & & 1 \\
\hline Morus bombycis & 1 & & 1 & & & & & 1 \\
\hline Morus spp. & 2 & & 2 & & & & & 2 \\
\hline Olea europaea & 1 & & 1 & & & & & 1 \\
\hline Olea spp. & 1 & & 1 & & & & & 1 \\
\hline Ostrya spp. & 1 & & 1 & & & & & 1 \\
\hline Parrotis spp. & 1 & & 1 & & & & & 1 \\
\hline Persea spp. & 1 & & 1 & & & & & 1 \\
\hline Persea thunbergii & 1 & & 1 & & & & & 1 \\
\hline Pholinia benthamiana & 1 & & 1 & & & & & 1 \\
\hline Pholinia spp. & 1 & & 1 & & & & & 1 \\
\hline Pinus massoniana & 1 & & 1 & & & & & 1 \\
\hline Pinus spp. & 3 & & 3 & & & 1 & & 2 \\
\hline Platanus hispanica & 1 & & 1 & & & & & 1 \\
\hline Platanus orientalis & 1 & & 1 & & & & & 1 \\
\hline Platanus spp. & 9 & & 8 & 1 & & 2 & & 7 \\
\hline Polygonum spp. & 2 & & 2 & & & & & 2 \\
\hline Poncitrus trifoliata & 1 & & 1 & & & & & 1 \\
\hline Poncitrus spp. & 1 & & 1 & & & & & 1 \\
\hline Populus alba & 1 & & 1 & & & & & 1 \\
\hline Populus maximowiczii & 1 & & 1 & & & & & 1 \\
\hline Populus nigra & 2 & & 2 & & & & & 2 \\
\hline Populus sieboldii & 1 & & 1 & & & & & 1 \\
\hline Populus spp. & 8 & & 8 & & & & & 8 \\
\hline Populus tomentosa & 1 & & 1 & & & & & 1 \\
\hline Prunus armeniaca & 1 & & 1 & & & & & 1 \\
\hline Prunus laurocerasus & 2 & & 2 & & & & & 2 \\
\hline Prunus mume & 1 & & 1 & & & & & 1 \\
\hline Prunus pseudocerasus & 1 & & 1 & & & & & 1 \\
\hline Prunus spp. & 5 & & 4 & 1 & & 1 & & 4 \\
\hline Prunus yedoensis & 1 & & 1 & & & & & 1 \\
\hline Psidium guajava & 1 & & 1 & & & & & 1 \\
\hline Psidium spp. & 1 & & 1 & & & & & 1 \\
\hline Pyracantha angustifolia & 1 & & 1 & & & & & 1 \\
\hline Pyracantha spp. & 1 & & 1 & & & & & 1 \\
\hline Pyrus hondoensis & 1 & & 1 & & & & & 1 \\
\hline Pyrus pyrifolia & 1 & & 1 & & & & & 1 \\
\hline Pyrus spp. & 8 & & 6 & 1 & 1 & 1 & & 7 \\
\hline Quercus acutissima & 1 & & 1 & & & & & 1 \\
\hline Quercus glauca & 1 & & 1 & & & & & 1 \\
\hline Quercus robur & 1 & & 1 & & & & & 1 \\
\hline Quercus serrata & 1 & & 1 & & & & & 1 \\
\hline Quercus sessilifolia & 1 & & 1 & & & & & 1 \\
\hline Quercus spp. & 5 & & 4 & 1 & & 1 & & 4 \\
\hline Rhododendron spp. & 3 & & 2 & 1 & & 1 & & 2 \\
\hline
\end{tabular}




\begin{tabular}{|c|c|c|c|c|c|c|c|c|}
\hline \multirow[b]{2}{*}{ Species } & \multirow[b]{2}{*}{$\begin{array}{l}\text { Total number } \\
\text { of studies }\end{array}$} & \multicolumn{4}{|c|}{ Numbers of articles } & \multicolumn{3}{|c|}{ Type of development } \\
\hline & & $\begin{array}{l}\text { Resistant/ } \\
\text { resilient }\end{array}$ & Host & $\begin{array}{l}\text { Good } \\
\text { host }\end{array}$ & $\begin{array}{l}\text { Very good } \\
\text { host }\end{array}$ & Full & $\begin{array}{l}\text { Feeding } \\
\text { development }\end{array}$ & $\begin{array}{l}\text { No } \\
\text { information }\end{array}$ \\
\hline$\overline{R h u s ~ j a v a n i c a}$ & 1 & & 1 & & & & & 1 \\
\hline Rhus spp. & 2 & & 2 & & & & & 2 \\
\hline Robinia pseudoacacia & 1 & & 1 & & & & & 1 \\
\hline Robinia spp. & 2 & & 2 & & & 1 & & 1 \\
\hline Rosa multiflora & 1 & & 1 & & & & & 1 \\
\hline Rosa spp. & 6 & & 5 & 1 & & 1 & & 5 \\
\hline Rubus microphyllus & 1 & & 1 & & & & & 1 \\
\hline Rubus palmatus & 1 & & 1 & & & & & 1 \\
\hline Rubus spp. & 2 & & 2 & & & & & 2 \\
\hline Sageretia spp. & 2 & & 2 & & & & & 2 \\
\hline Salix babylonica & 1 & & 1 & & & & & 1 \\
\hline Salix gracilistyla & 1 & & 1 & & & & & 1 \\
\hline Salix integra & 1 & & 1 & & & & & 1 \\
\hline Salix jessoensis & 1 & & 1 & & & & & 1 \\
\hline Salix koriyanagi & 1 & & 1 & & & & & 1 \\
\hline Salix sachalinensis & 1 & & 1 & & & & & 1 \\
\hline Salix spp. & 8 & & 7 & 1 & & 1 & & 7 \\
\hline Sambucus spp. & 1 & & 1 & & & & & 1 \\
\hline Sapium sebiferum & 1 & & 1 & & & & & 1 \\
\hline Sapium spp. & 1 & & 1 & & & & & 1 \\
\hline Sophora spp. & 2 & & 2 & & & & & 2 \\
\hline Sorbus spp. & 2 & & 1 & 1 & & 1 & & 1 \\
\hline Stranvaesia benthamiana & 1 & & 1 & & & & & 1 \\
\hline Stranvaesia spp. & 1 & & 1 & & & & & 1 \\
\hline Styrax japonica & 1 & & 1 & & & & & 1 \\
\hline Styrax spp. & 1 & & 1 & & & & & 1 \\
\hline Toona spp. & 1 & & 1 & & & & & 1 \\
\hline Toxicodendron verniciflua & 1 & & 1 & & & & & 1 \\
\hline Ulmus davidiana var. japonica & 1 & & 1 & & & & & 1 \\
\hline Ulmus pumila & 1 & & 1 & & & & & 1 \\
\hline Ulmus spp. & 5 & & 4 & 1 & & 1 & & 4 \\
\hline Vernicia spp. & 1 & & 1 & & & & & 1 \\
\hline Viburnum spp. & 2 & & 2 & & & & 1 & 1 \\
\hline Zelkova spp. & 1 & & 1 & & & 1 & & \\
\hline Ziziphus spp. & 1 & & 1 & & & & & 1 \\
\hline
\end{tabular}




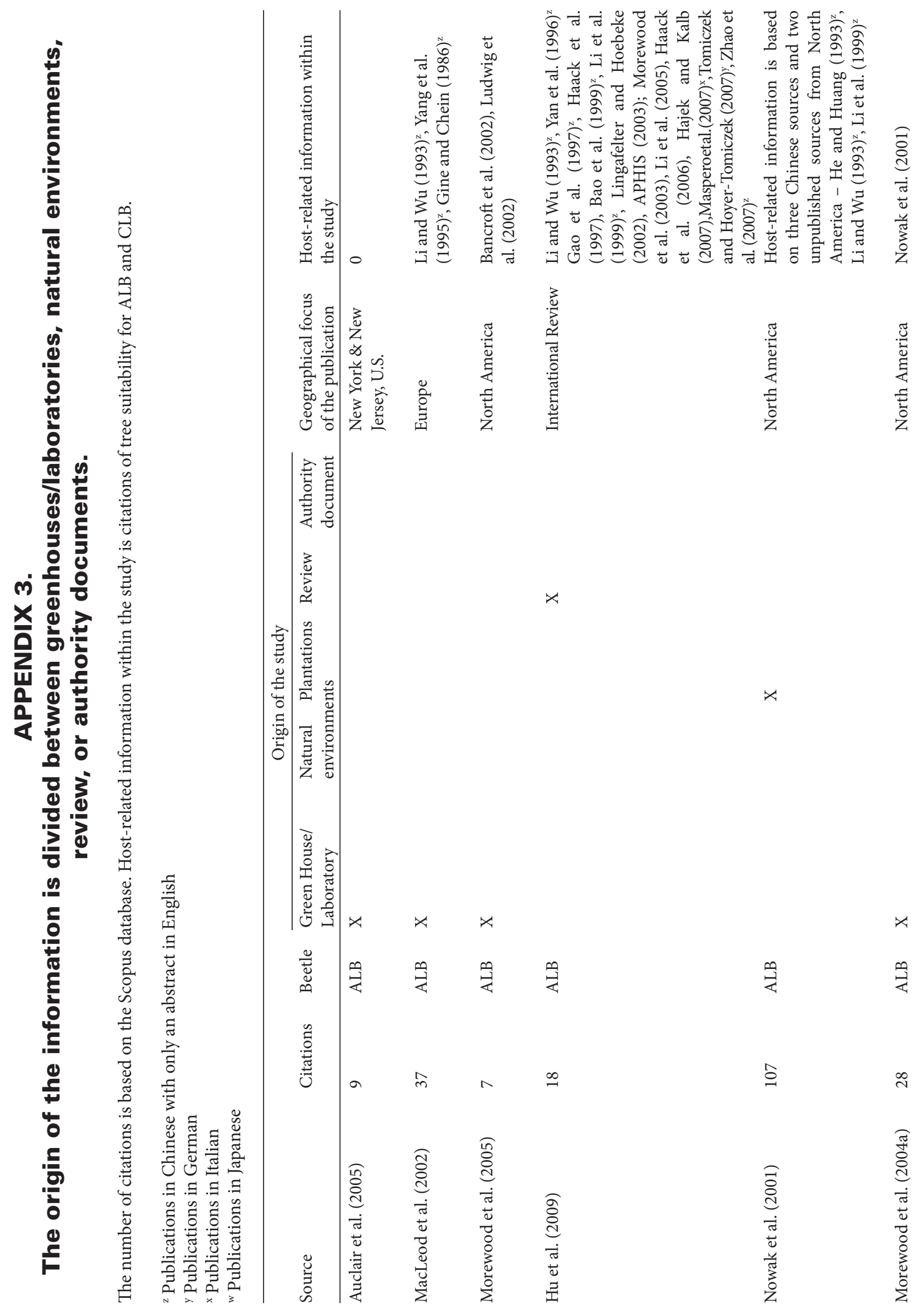




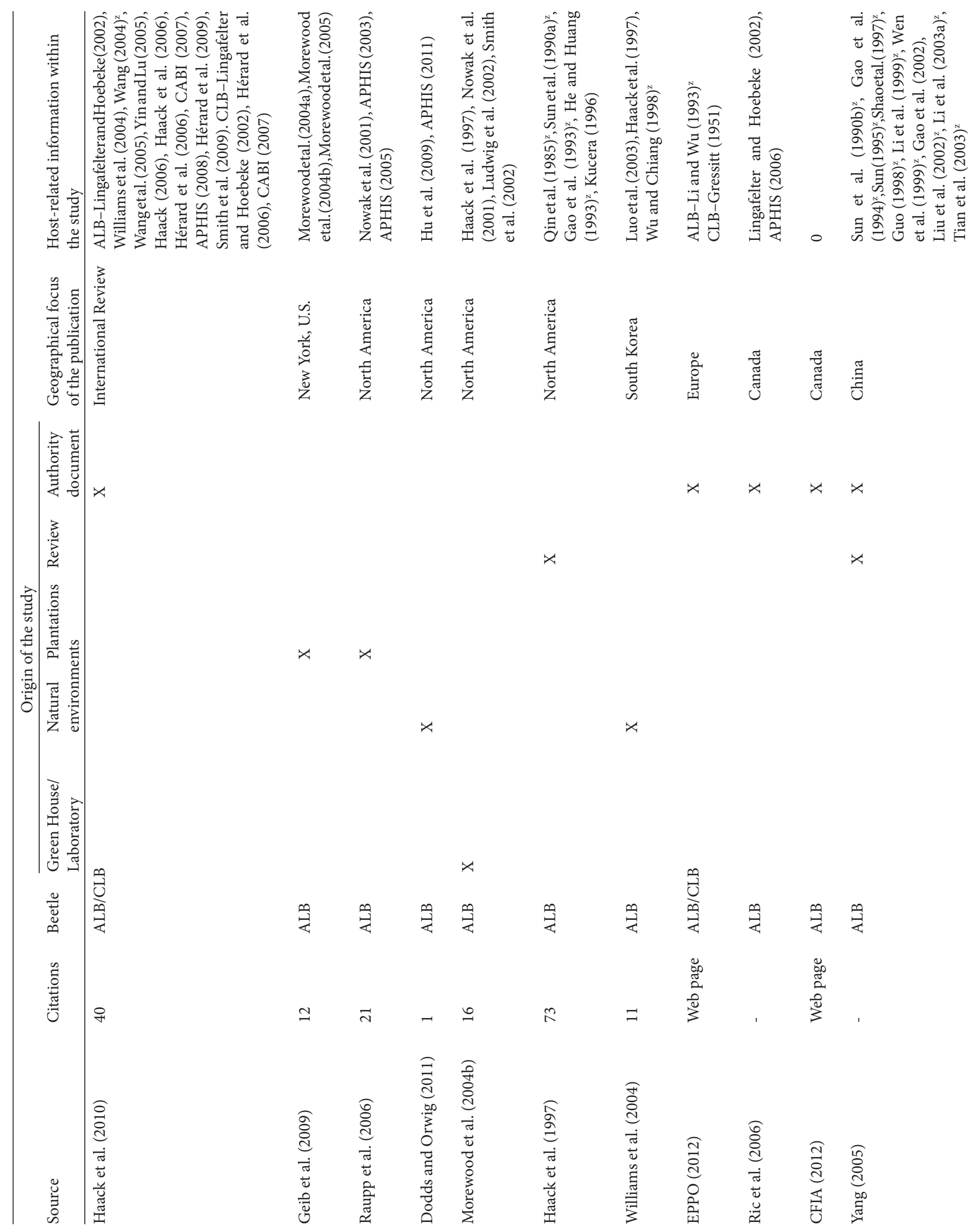




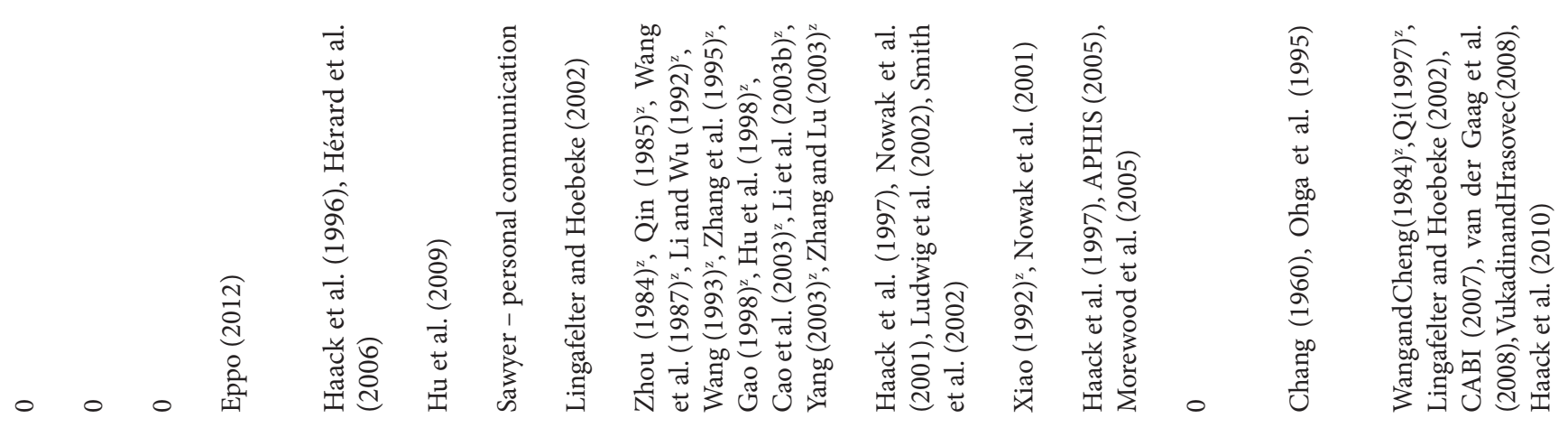
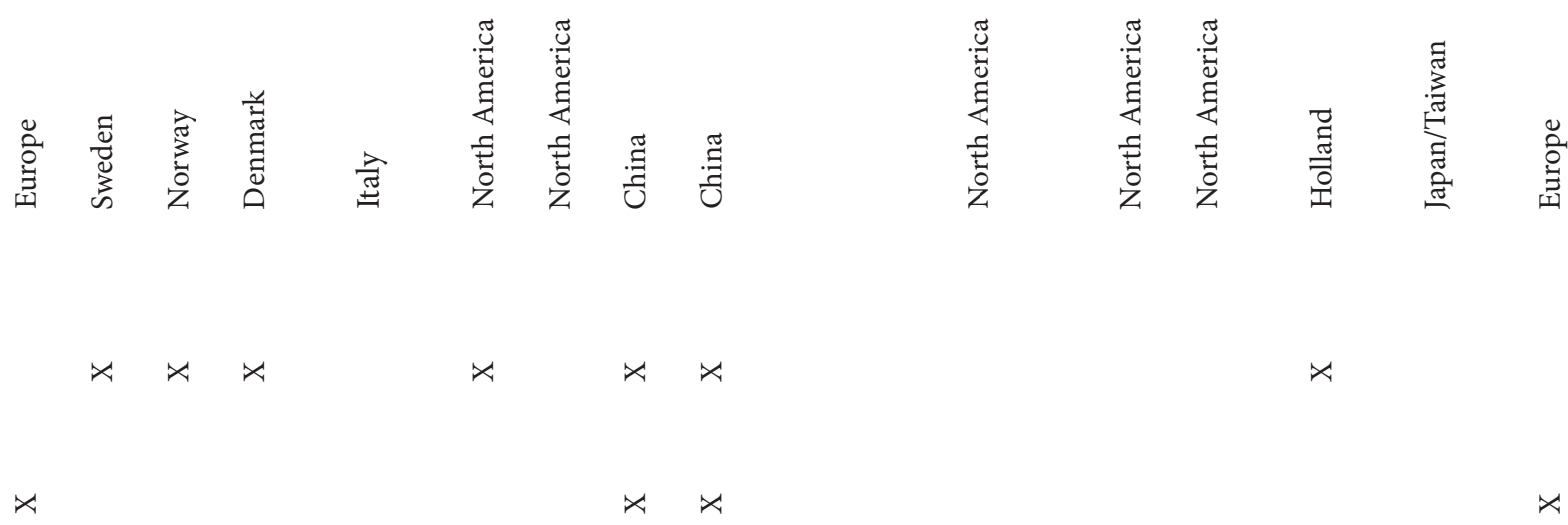

$x$

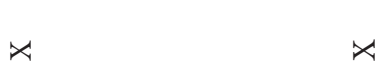

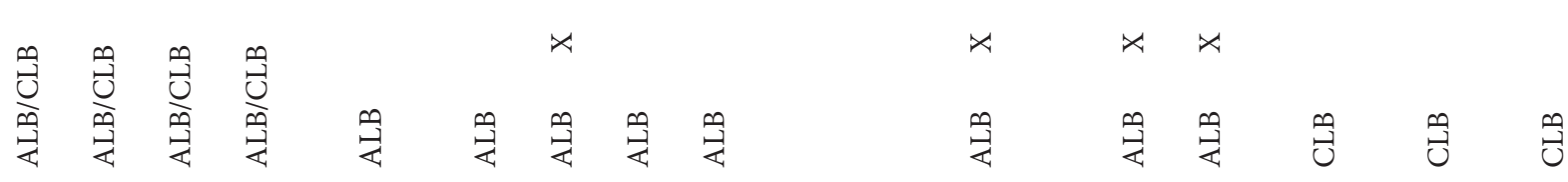

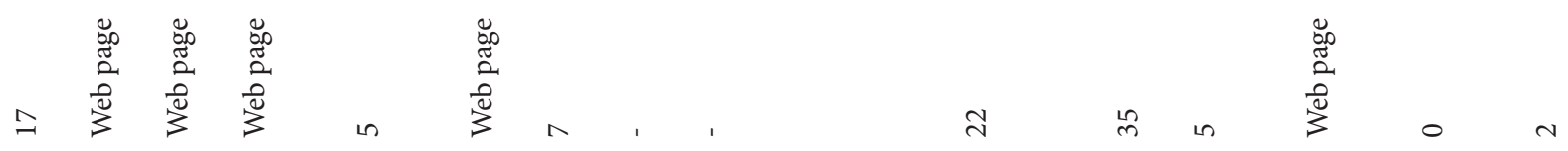

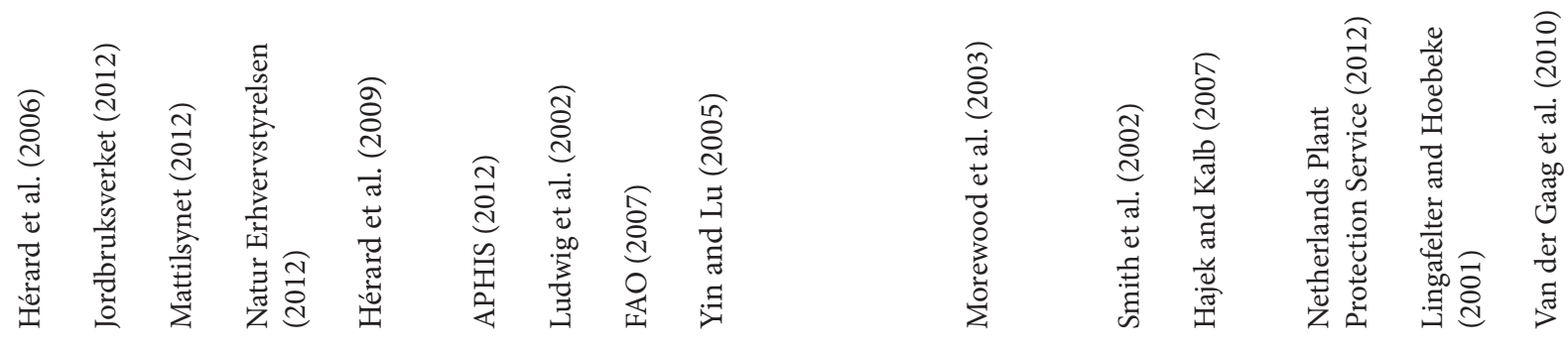




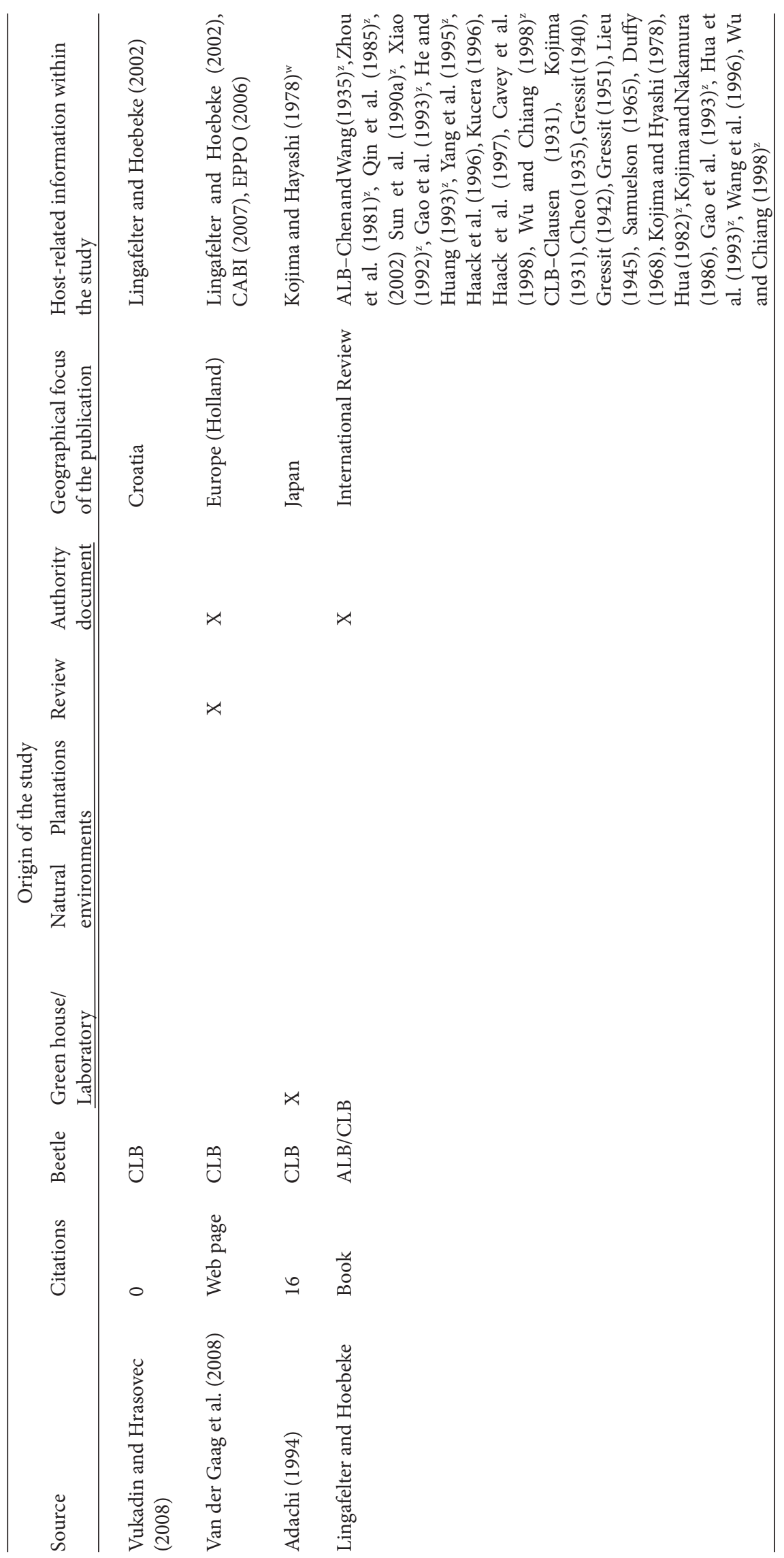

C2014 International Society of Arboriculture 